\title{
Article
}

\section{The AP-1 Transcription Factor Fosl-2 Regulates Autophagy in Cardiac Fibroblasts during Myocardial Fibrogenesis}

\author{
Jemima Seidenberg ${ }^{1,+} \oplus$, Mara Stellato ${ }^{1,+}$, Amela Hukara $^{1}$, Burkhard Ludewig ${ }^{2,3}$, Karin Klingel ${ }^{4}$, \\ Oliver Distler ${ }^{1}$, Przemysław Błyszczuk ${ }^{1,5}$ (D) and Gabriela Kania $1, *$ (D) \\ 1 Center of Experimental Rheumatology, Department of Rheumatology, University Hospital Zurich, \\ University of Zurich, 8952 Schlieren, Switzerland; jemimaseidenberg@gmail.com (J.S.); \\ Mara.Stellato@usz.ch (M.S.); Amela.Hukara@usz.ch (A.H.); Oliver.Distler@usz.ch (O.D.); \\ przemyslaw.blyszczuk@uzh.ch or przemyslaw.blyszczuk@uj.edu.pl (P.B.) \\ 2 Institute of Immunobiology, Cantonal Hospital St. Gallen, 9007 St. Gallen, Switzerland; \\ burkhard.ludewig@kssg.ch \\ 3 Institute of Experimental Immunology, University of Zurich, 8057 Zurich, Switzerland \\ 4 Cardiopathology, Institute for Pathology and Neuropathology, University Hospital Tubingen, \\ D-72076 Tubingen, Germany; Karin.Klingel@med.uni-tuebingen.de \\ 5 Department of Clinical Immunology, Jagiellonian University Medical College, 30-663 Krakow, Poland \\ * Correspondence: gabriela.kania@uzh.ch \\ + These authors contributed equally to this manuscript.
}

check for updates

Citation: Seidenberg, J.; Stellato, M.; Hukara, A.; Ludewig, B.; Klingel, K.; Distler, O.; Błyszczuk, P.; Kania, G. The AP-1 Transcription Factor Fosl-2 Regulates Autophagy in Cardiac Fibroblasts during Myocardial Fibrogenesis. Int. J. Mol. Sci. 2021, 22, 1861. https://doi.org/10.3390/ ijms22041861

Academic Editor:

Hideyuki Yamawaki

Received: 19 January 2021

Accepted: 9 February 2021

Published: 13 February 2021

Publisher's Note: MDPI stays neutral with regard to jurisdictional claims in published maps and institutional affiliations.

Copyright: (c) 2021 by the authors Licensee MDPI, Basel, Switzerland. This article is an open access article distributed under the terms and conditions of the Creative Commons Attribution (CC BY) license (https:// creativecommons.org/licenses/by/ $4.0 /)$.

\begin{abstract}
Background: Pathological activation of cardiac fibroblasts is a key step in development and progression of cardiac fibrosis and heart failure. This process has been associated with enhanced autophagocytosis, but molecular mechanisms remain largely unknown. Methods and Results: Immunohistochemical analysis of endomyocardial biopsies showed increased activation of autophagy in fibrotic hearts of patients with inflammatory cardiomyopathy. In vitro experiments using mouse and human cardiac fibroblasts confirmed that blockade of autophagy with Bafilomycin A1 inhibited fibroblast-to-myofibroblast transition induced by transforming growth factor (TGF)- $\beta$. Next, we observed that cardiac fibroblasts obtained from mice overexpressing transcription factor Fos-related antigen 2 (Fosl-2tg) expressed elevated protein levels of autophagy markers: the lipid modified form of microtubule-associated protein 1A/1B-light chain 3B (LC3BII), Beclin-1 and autophagy related 5 (Atg5). In complementary experiments, silencing of Fosl-2 with antisense GapmeR oligonucleotides suppressed production of type I collagen, myofibroblast marker alpha smooth muscle actin and autophagy marker Beclin-1 in cardiac fibroblasts. On the other hand, silencing of either LC3B or Beclin-1 reduced Fosl-2 levels in TGF- $\beta$-activated, but not in unstimulated cells. Using a cardiac hypertrophy model induced by continuous infusion of angiotensin II with osmotic minipumps, we confirmed that mice lacking either Fosl-2 (Ccl19CreFosl2flox/flox) or Atg5 (Ccl19CreAtg5flox/flox) in stromal cells were protected from cardiac fibrosis. Conclusion: Our findings demonstrate that Fosl-2 regulates autophagocytosis and the TGF- $\beta$-Fosl-2-autophagy axis controls differentiation of cardiac fibroblasts. These data provide a new insight for the development of pharmaceutical targets in cardiac fibrosis.
\end{abstract}

Keywords: autophagy; cardiac fibrosis; cardiac fibroblasts; Fos-related antigen 2; cardiac hypertrophy

\section{Introduction}

Cardiac fibrosis is characterized by the excessive deposition of type I collagen and other extracellular matrix proteins in the cardiac tissue. In non-inflammatory heart disease, this process is mediated mainly by activated cardiac fibroblasts and pathological myofibroblasts [1]. Fibrotic changes in the myocardium cause stiffening of the ventricles that may lead to development of cardiomyopathies and impairment in systolic and diastolic heart functions [2]. It has been hypothesized that autophagy may play an important role in cardiac fibrogenesis. 
Autophagy, also called autophagocytosis, refers to processes of controlled cellular selfdegradation and recycling in response to nutrient deprivation and other cellular stresses. Activation of the autophagocytosis is essential not only for cell survival but plays an important role also in cell homeostasis and during cell differentiation [3]. Autophagy is an evolutionarily conserved process, in which the double membrane vesicle (phagophore) forms autophagosome with cargo proteins that in the next step fuses with a lysosome for the digestion of the content. This process is tightly regulated by specific effector molecules, including a number of autophagy-related (Atg) proteins, Beclin-1 and the cytosolic microtubule-associated protein light-chain 3 beta (LC3B), that represent the most common markers for autophagy monitoring. The family of Atg proteins plays a crucial role in formation of the phagophore, whereas Beclin-1 is an adaptor protein that enables the recruitment of other autophagy proteins involved in the nucleation of the autophagosome. In case of LC3B, a cleaved form of the cytosolic LC3B (LC3B I) is conjugated to phosphatidylethanolamine forming LC3B II that is attached on the surface of newly generated autophagosomes and promotes its maturation [4].

In homeostatic condition, autophagy plays a cardioprotective role by mediating organelle turnover, recycling aged or damaged cytoplasmic components, thereby protecting from aging and development of cardiovascular disease [5]. In particular, defective autophagy leads to cardiac hypertrophy associated with cardiac fibrosis and contractile dysfunction [6-8]. Unlike in homeostasis, the role of autophagocytosis in fibrotic heart disease is less clear. In hypertrophic heart, autophagic processes are activated and studies on Beclin-1 suggested that autophagy enhanced tissue remodeling and disease progression $[9,10]$. In line with these results, treatment with autophagy inhibitor chloroquine ameliorated diastolic function and cardiac fibrosis in diabetic mice [11]. On the other hand, genetic deficiency of autophagy effector protein Atg5 led to increased hypertrophy and cardiac fibrosis $[8,12]$. Similarly, blunting autophagy accelerated cardiac fibrosis and ventricular dysfunction in a mouse model of desmin-related cardiomyopathy [13].

Involvement of autophagy to cellular and molecular processes is cell type-specific. A growing body of evidence suggests that the autophagy plays a critical role in cardiomyocytes [14]. Unlike for cardiomyocytes, much less is known about the role of autophagocytosis in cardiac fibroblasts. In vitro experiments showed enhanced autophagy in activated cardiac, but also dermal fibroblasts undergoing fibroblast-to-myofibroblast transition [15,16]. Inhibition of autophagocytosis by treatment with bafilomycin A1 (BafA1) and chloroquine reduced formation of myofibroblast and cell mobility [17]. Fibroblast-tomyofibroblast transition can be induced by various molecular triggers, however transforming growth factor (TGF)- $\beta$ represents a master profibrotic cytokine that most effectively activates myofibroblastic fate of cardiac fibroblasts [18,19]. Of note, TGF- $\beta$ signaling has been suggested to promote LC3B I to LC3B II conversion and autophagosome formation through its canonical and non-canonical pathways $[18,20]$. Profibrotic TGF- $\beta$ signaling is well-known to interplay with other profibrotic pathways [21]. Fos-like 2 (Fosl-2, known also as Fra-2) represents a transcription factor of the activator protein (AP)-1 family that like TGF- $\beta$ has been associated with fibrotic processes. Mice overexpressing Fosl-2 (Fosl-2 ${ }^{\text {tg }}$ ) develop spontaneous autoimmunity and multiorgan fibrosis including skin, lung and the heart [22-24]. So far, regulation of autophagocytosis by Fosl-2 remains unknown.

\section{Results}

\subsection{Autophagy Enhances Myofibroblast Activation of Cardiac Fibroblasts}

To evaluate the relevance of autophagy in fibrotic heart disorders, we analyzed expression of autophagy-related proteins LC3B, Beclin-1 and ATG5 in endomyocardial biopsies obtained from iDCM patients who developed fibrotic phenotype in comparison to patients with healed myocarditis (no fibrosis). Myocardial tissue of iDCM patients was characterized by increased fibrosis and elevated levels of autophagy markers: ATG5, Beclin-1 and LC3B (Figure 1). Such association might suggest potential involvement of autophagy in cardiac fibrosis. 
A

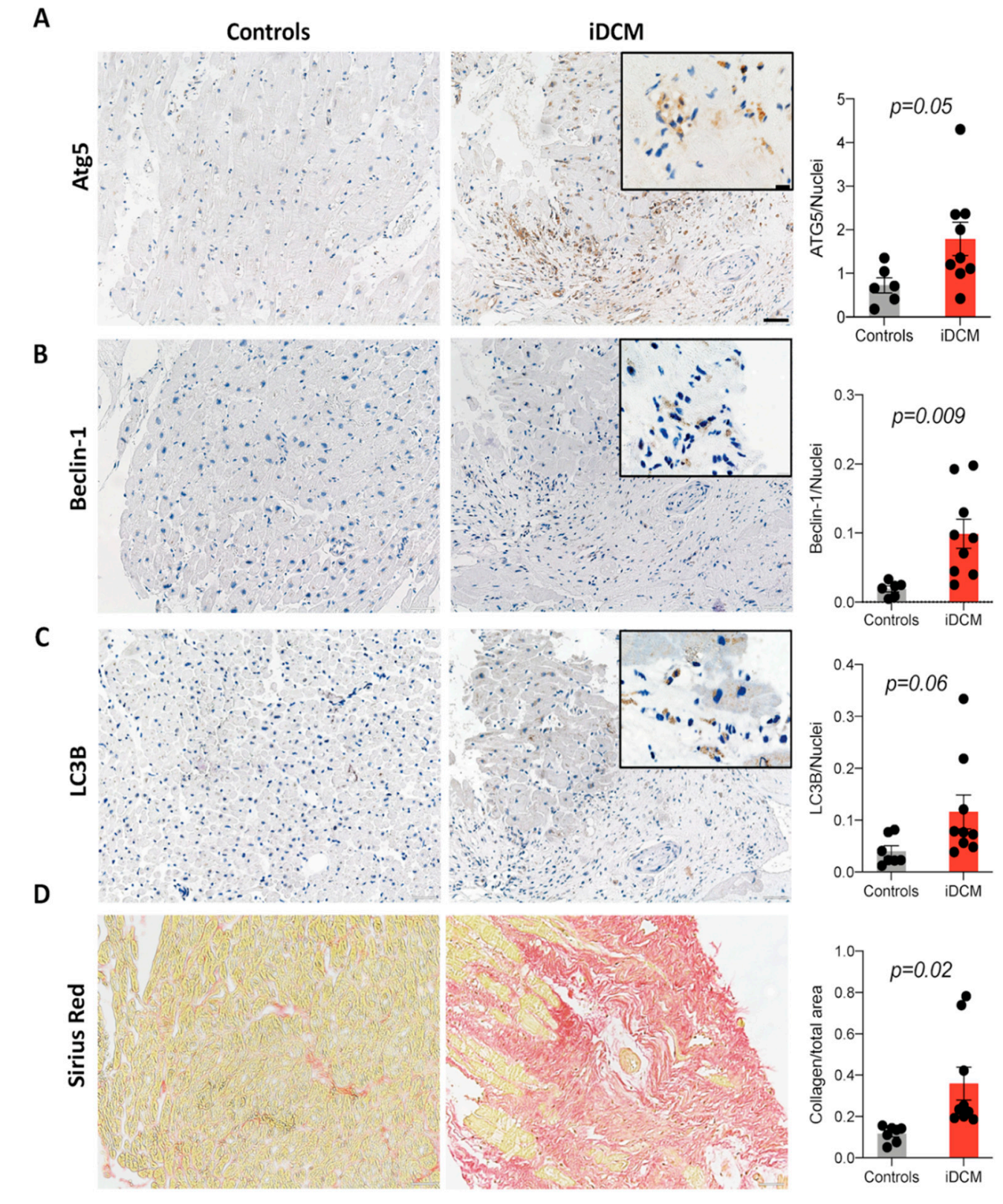

B
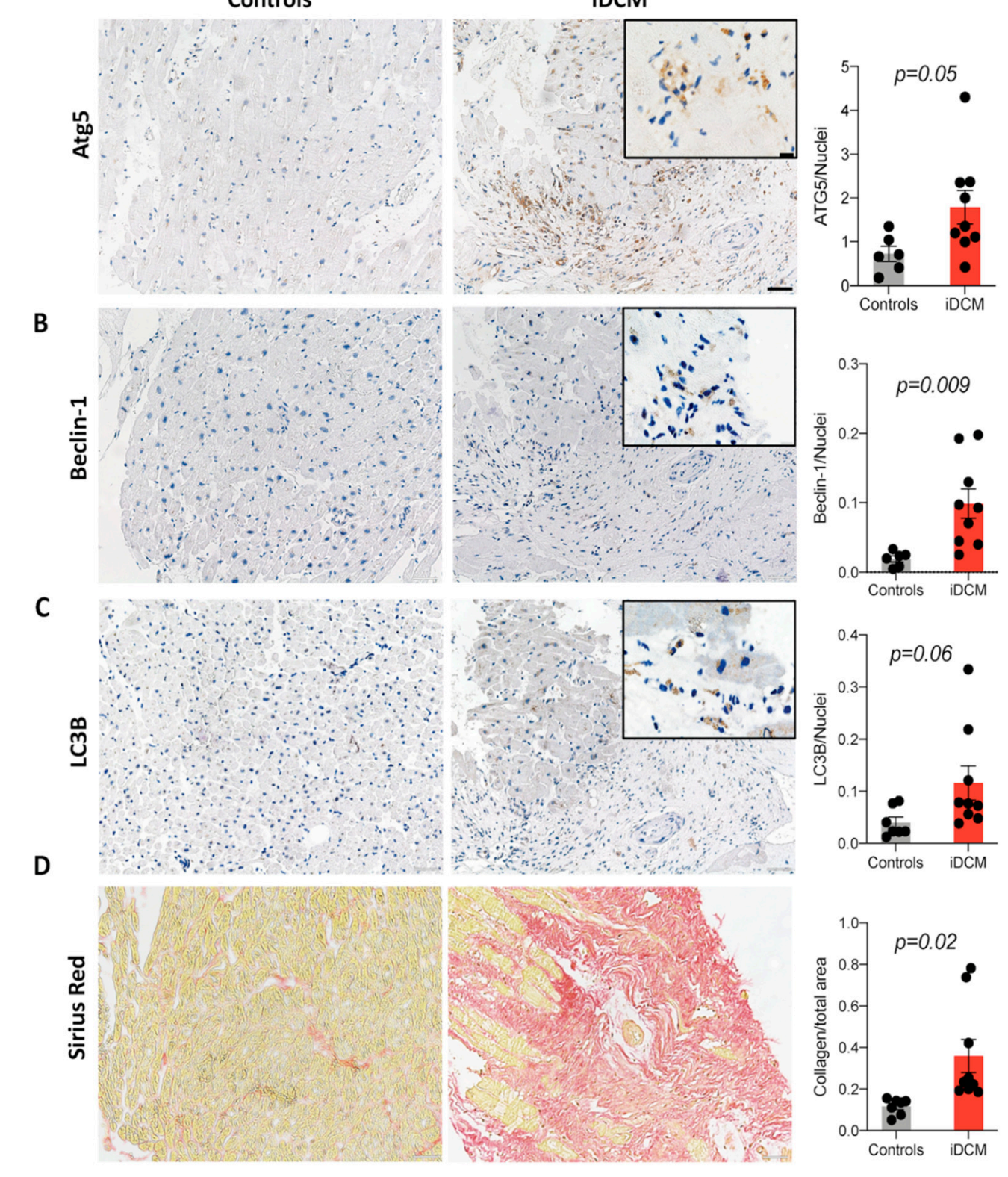

iDCM

Figure 1. Autophagy process is activated in human hearts of iDCM patients. Representative pictures and relative quantification of ATG5 (A), Beclin-1 (B), and LC3B (C) IHC and Sirius Red staining (D) for collagen deposition in endomyocardial biopsies of controls (healed myocarditis) and iDCM patients ( $\mathrm{n}=6-9$, unpaired $t$-test). Scale bars: $50 \mu \mathrm{m}$, scale bars in inserts: $20 \mu \mathrm{m}$.

Serum deprivation is a common method to activate autophagy in vitro. In the first set of experiments, we analyzed how cardiac fibroblasts upregulate autophagy-associated proteins in response to a switch from $10 \%$ to $1 \%$ serum in cell culture medium. As expected, we observed upregulation of LC3B I and LC3B II proteins (Figure 2A,B and Figure S1A,B). It should be noted that the LC3B II form is mostly associated with formation of autophagosomes. Upon exposure to cell culture medium containing 1\% serum, mouse and human cardiac fibroblasts also upregulated two other autophagy-associated proteins, Beclin-1 and Atg 5 (Figure 2A,B and Figure S1A,B). Fibroblasts cultured in pro-autophagic condition (1\% serum) were also treated with the profibrotic cytokine TGF- $\beta$. In the presence of TGF- $\beta$, cardiac fibroblasts maintained elevated levels of LC3B, Beclin- 1 and Atg 5 induced by the low serum medium (Figure 2A,B and Figure S1A,B). 
A

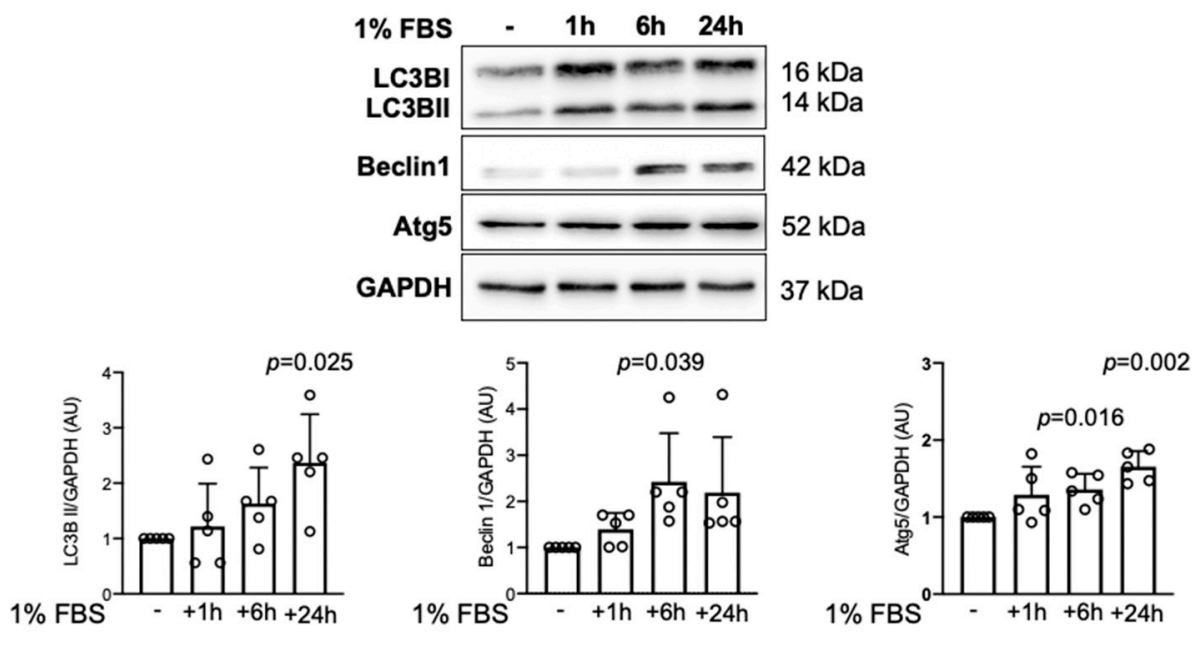

B
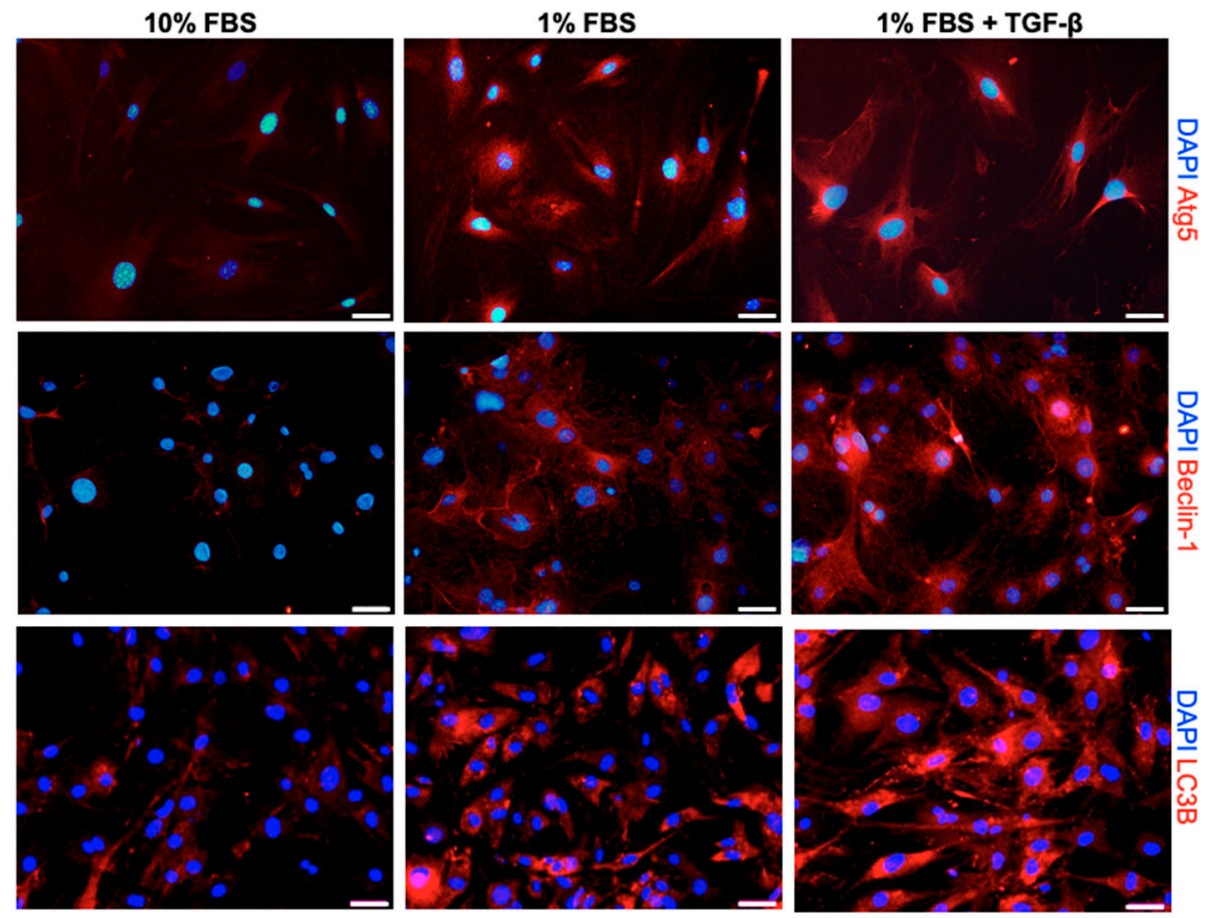

Figure 2. Autophagy activation in cardiac fibroblasts. (A) Representative pictures and densitometry analysis of immunoblots of mouse cardiac fibroblasts (one-way analysis of variance (ANOVA), $n=5$ ). (B) Representative pictures of LC3B, Atg 5 and Beclin- 1 immunostaining (red) of cardiac fibroblasts, cultured in medium containing $10 \%$ or $1 \%$ fetal bovine serum (FBS) with or without TGF- $\beta$ for $24 \mathrm{~h}$ $(\mathrm{n}=3)$. Nuclei are stained with DAPI (blue). Scale bars: $20 \mu \mathrm{m}$.

In order to address how autophagy regulates cardiac fibrosis, we analyzed activation of cardiac fibroblasts in the presence of BafA1, an autophagy inhibitor, which blocks fusion of autophagosome with lysosomes, leading to accumulation of autophagosomes. We confirmed that BafA1 effectively inhibited degradation of autophagosomes in cardiac fibroblasts, as indicated by accumulation of autophagosome-associated LC3B II protein in the presence of TGF- $\beta$ (Figures S1A and S2A). Importantly, TGF- $\beta$ stimulation increased Fosl-2 protein expression (Figure 3B and Figure S2B). Formation of $\alpha$ SMA-positive, highly contractile myofibroblasts is a hallmark of TGF- $\beta$-dependent activation of cardiac fibroblasts. We observed reduced $\alpha$ SMA protein levels in cardiac fibroblasts treated with BafA1 (Figure 3A and Figure S1A). In line with this result, BafA1 reduced contractility of TGF- $\beta$ activated cardiac fibroblasts in the collagen gel contraction assay (Figure $3 \mathrm{C}$ and Figure 
S1D). Treatment with BafA1 suppressed secretion of type I collagen in the presence and in the absence of profibrotic TGF- $\beta$ (Figure 3D and Figure S1C). On the molecular level, BafA1 blocked activation of the TGF- $\beta$ canonical Smad-dependent pathway, as indicated by inhibited phosphorylation of Smad2 (Figure 3E). Furthermore, treatment of cardiac fibroblasts with BafA1 inhibited cell proliferation and increased caspase 3/7 activity, suggesting increased apoptosis (Figure 3F,G).

A

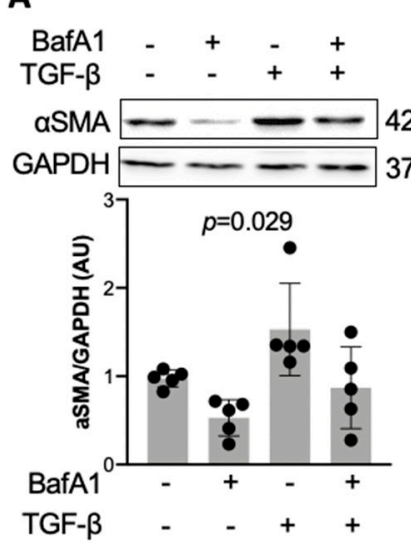

D

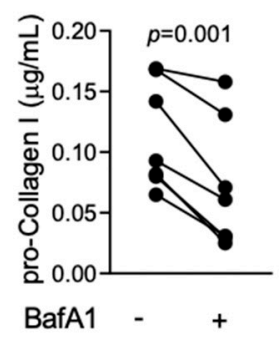

E

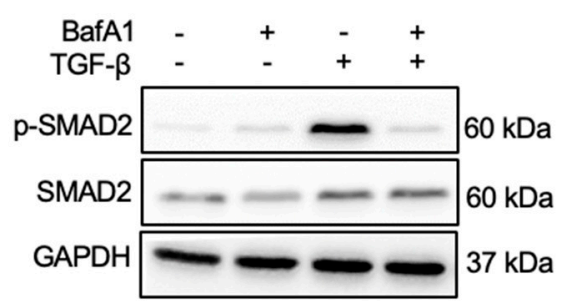

B

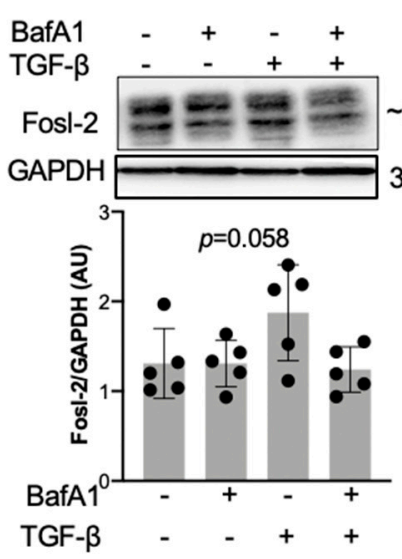

$\mathbf{F}$

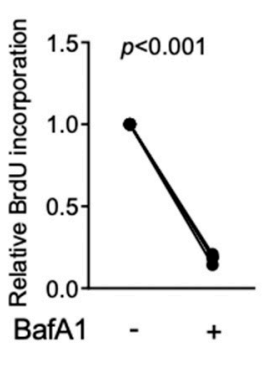

C
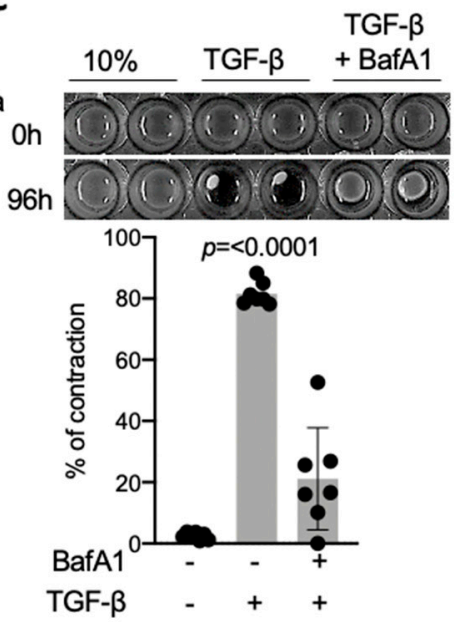

G

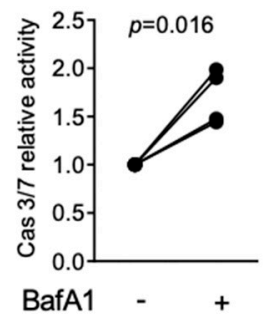

Figure 3. Autophagy blockage with BafA1 protects from TGF- $\beta$-induced fibroblast-to-myofibroblast transition. $(\mathbf{A}, \mathbf{B})$ Mouse cardiac fibroblasts were cultured in the presence or absence of $10 \mathrm{ng} / \mathrm{mL}$ TGF- $\beta$ for $48 \mathrm{~h}$ with or without $4 \mathrm{~h}$ pre-treatment with $50 \mathrm{nM}$ BafA1. Representative immunoblots and corresponding quantification of $\alpha \mathrm{SMA}$ (A) and Fosl-2 (B) protein levels (one-way ANOVA, $n=5$ ). (C) Representative pictures and corresponding quantification of collagen gel contraction at 0 and $96 \mathrm{~h}$ after seeding cells in a collagen gel. Cells were pre-treated with BafA1 for $4 \mathrm{~h}$ and then stimulated with TGF- $\beta$ where indicated (one-way ANOVA, $n=7$ ). (D) Measurements of pro-collagen I levels in supernatants of cardiac fibroblasts pre-treated with BafA1 for $4 \mathrm{~h}$ (paired $t$-test, $\mathrm{n}=6$ ). (E) Representative immunoblots and corresponding quantification of p-SMAD2/SMAD2 levels of cardiac fibroblasts pre-treated with BafA1 for $4 \mathrm{~h}$ and stimulated with TGF- $\beta$ for $1 \mathrm{~h}$ (one-way ANOVA, $n=4)$. BrdU proliferation assay $(F)$ and caspase $3 / 7$ apoptosis assay $(G)$ of cardiac fibroblasts pre-treated with BafA1 for $4 \mathrm{~h}$ (both paired $t$-test, $\mathrm{n}=4$ ). 


\subsection{Fosl-2 Controls Autophagocytosis in Cardiac Fibroblasts}

In the next step, we asked how the AP-1 transcription factor Fosl-2 affects autophagocytosis of cardiac fibroblasts. Analysis of cardiac tissues obtained from Fosl-2 ${ }^{\text {tg }}$ (overexpressing Fosl2) mice clearly showed elevated levels of LC3B in transgenic animals (Figure 4A). Next, we isolated cardiac fibroblasts from Fosl-2 ${ }^{\text {tg }}$ and control (Fosl-2 ${ }^{\text {wt }}$ ) mice and analyzed expression of autophagy-related markers. We found that under control ( $10 \%$ serum) condition, Fosl- ${ }^{\operatorname{tg}}$ cardiac fibroblasts showed elevated LC3B II, Beclin-1 and Atg5 protein levels (Figure 4B). Immunofluorescent analysis confirmed increased levels of LC3B and Atg5 in Fosl-2 ${ }^{\text {tg }}$ cells under the non-stimulatory condition and in the presence of TGF$\beta$ (Figure 4C,D). Of note, treatment with BafA1 increased LC3B II, but not autophagy adaptor protein p62 in Fosl-2 ${ }^{\text {tg }}$ cardiac fibroblasts (Figure 4E), indicating that increased levels of LC3B II in Fosl-2 ${ }^{\text {tg }}$ cardiac fibroblasts were caused by higher levels of ongoing autophagy rather than accumulation of autophagosomes due to impaired autophagy. Electron microscopy analysis confirmed more autophagosomes in Fosl-2 ${ }^{\text {tg }}$ cells (Figure 4F).

Overexpression of Fosl-2 led to enhanced autophagocytosis in cardiac fibroblasts, therefore, in the next step, we analyzed the role of Fosl-2 using the loss-of-function approach. To this aim, we silenced Fosl 2 mRNA (using antisense oligonucleotides) in cardiac fibroblasts and analyzed expression of profibrotic and autophagy-related markers. The silencing successfully reduced Fosl-2 protein level by 50\% (Figure 5A,B). On the one hand, Fosl2 silencing reduced production of type I collagen at the transcript and protein levels (Figure 5C,D). Similarly, Fosl2-silenced fibroblasts were characterized by a lower expression of Acta2 (gene encoding $\alpha \mathrm{SMA}$, Figure $5 \mathrm{C}$ ), reduced $\alpha \mathrm{SMA}$ total protein content (Figure 5E) and showed the absence of $\alpha$ SMA-positive stress fibers (Figure 5F). On the other hand, silencing of Fosl2 suppressed autophagocytosis only under the pro-autophagic condition ( $1 \%$ serum) in the presence of TGF- $\beta$, as indicated by reduced protein content of Beclin-1 (Figure $5 \mathrm{G}, \mathrm{H}$ ). It should be noted that TGF- $\beta$ is a potent activator of Fosl-2 (Figure 2B and Figure S2), which could explain the requirement of stimulatory condition to observe the Fosl-2-dependent effect in the loss-of-function approach.

\subsection{Autophagy Regulates Fosl-2 in Cardiac Fibroblasts}

As shown above, Fosl-2, under fibrotic conditions, regulated autophagocytosis, therefore, in the next step, we addressed whether blockade of autophagy process could, in turn, modulate Fosl-2 levels. Inhibition of autophagocytosis with BafA1 effectively reduced protein Fosl-2 level in cardiac fibroblasts (Figure 3B), pointing to an autoregulatory feedback loop mechanism. Next, we analyzed the role of individual autophagy proteins LC3B and Beclin-1 in regulation of Fosl-2. Silencing of LC3B in cardiac fibroblasts resulted in 50\% reduced LC3B protein levels (Figure 6A). We found that cells with reduced LC3B showed less Fosl-2, however only in the presence of TGF- $\beta$ (Figure 6A). In contrast, Beclin-1 levels in cells with silenced LC3B remained unaffected (Figure 6A). In our experiments, Beclin-1, similarly to LC3B, regulated Fosl-2. Silencing of Beclin-1 (50\% protein reduction, Figure $6 \mathrm{~B})$ reduced Fosl-2 levels in cardiac fibroblasts in the presence, but not in the absence, of TGF- $\beta$ (Figure $6 \mathrm{~B}$ ). Furthermore, we found that in the pro-autophagic condition, loss of Beclin-1 was associated with loss of LC3B (Figure 6B).

\subsection{Expression of Fosl-2 and Atg5 in Cardiac Fibroblasts Control Cardiac Fibrosis in a Mouse Model of Cardiac Hypertrophy}

Our in vitro data indicated that interplay between Fosl-2 and autophagy plays a crucial role in profibrotic changes in cardiac fibroblasts. To address whether these mechanisms are relevant during fibrogenesis in vivo, we analyzed fibrotic changes, using a model of experimental cardiac hypertrophy, in mice lacking either Fosl-2 or Atg5 in stromal cells using Ccl19 ${ }^{\mathrm{Cre}} \mathrm{Fos} 12^{\text {flox/flox }}$ and $\mathrm{Ccl} 19^{\mathrm{Cre}} \mathrm{Atg} 5^{\text {flox/flox }}$ strains (Ccl19 is expressed in stromal cells ${ }^{25}$ ), induced by continuous infusion of the vasoconstrictor angiotensin II delivered by osmotic minipumps. Continuous infusion of exogenous angiotensin II led to increased heart weight, collagen deposition and induced expression of Fosl-2 and Atg5 
in mouse hearts (Figure S3A-D). We observed that 3 weeks after angiotensin II infusion, hearts of $\mathrm{Ccl19}{ }^{\mathrm{Cre}} \mathrm{Fosl2} 2^{\text {flox/flox }}$ mice showed less collagen deposition, decreased number of gp38-expressing fibroblasts (Figure 7A,B) and reduced number of Atg5-positive cells in comparison to hearts of control Fosl $2^{\text {flox/flox }}$ mice (Figure S4A), confirming the profibrotic role of Fosl-2 in cardiac fibroblasts. A similar phenotype was found in mice lacking Atg5 in stromal cells. In the angiotensin II-mediated cardiac hypertrophy model, hearts isolated from $\mathrm{Ccl} 19^{\mathrm{Cre}} \mathrm{Atg} 5^{\text {flox/flox }}$ mice were not only protected from increased collagen content, but also showed less gp38-expressing and Fosl-2-expressing fibroblasts and $\alpha$ SMA-positive myofibroblasts in comparison to controls (Figure 7C-E and Figure S4B,C). All these results confirmed the functional involvement of Fosl-2 and autophagy in cardiac fibrosis.
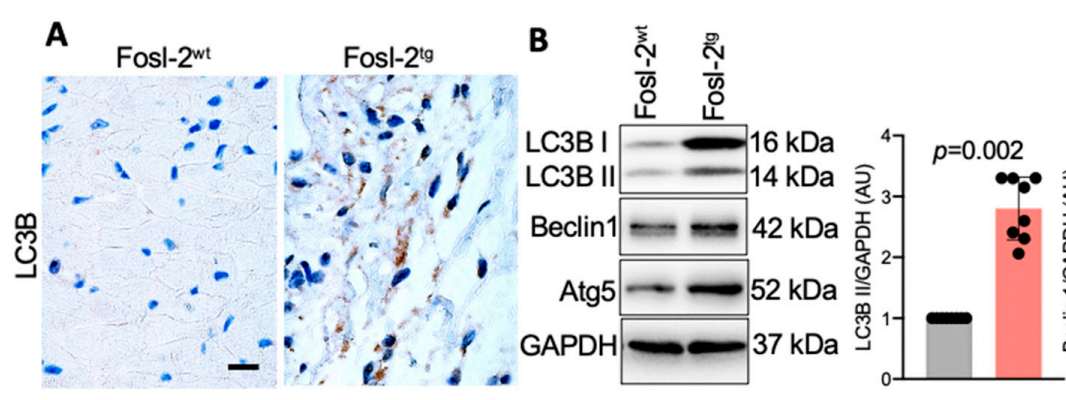

Fosl-2wt

Fosl-2tg
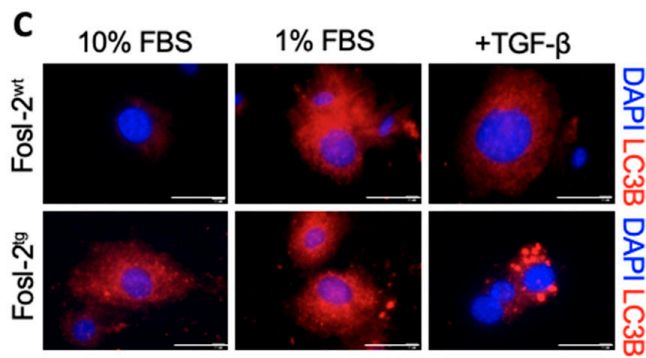

D
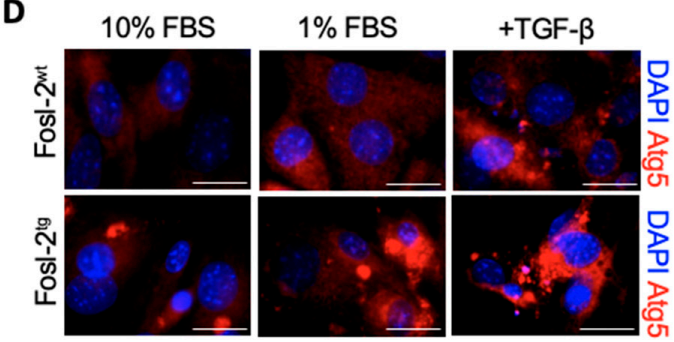

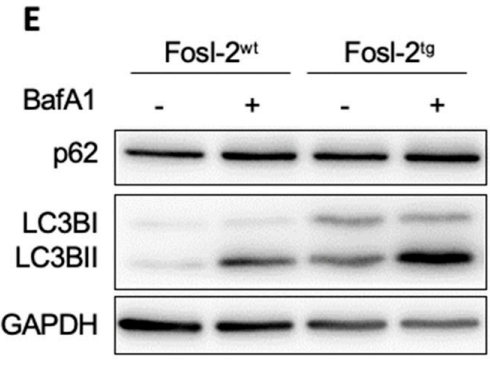

$\mathbf{F}$
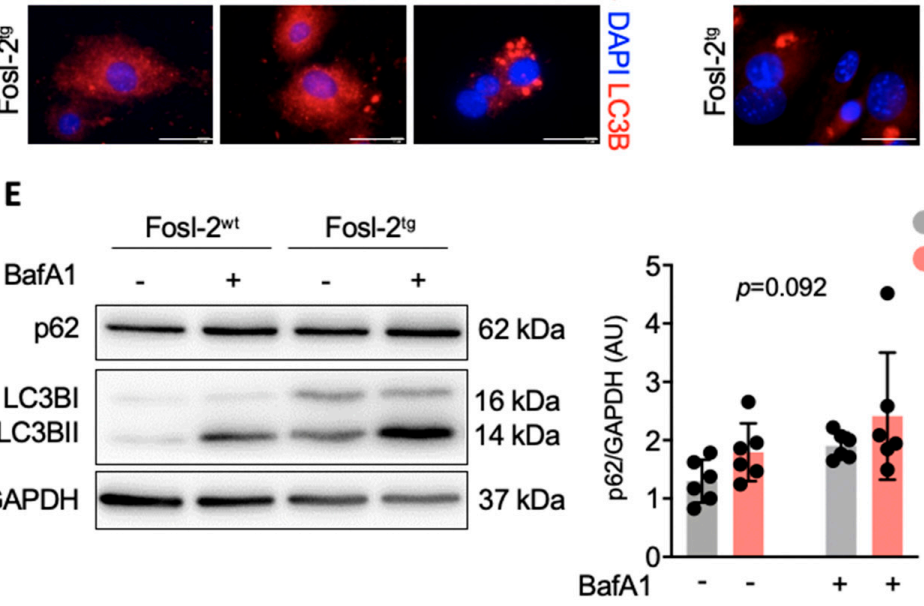

Fosl-2wt

Fosl-2tg
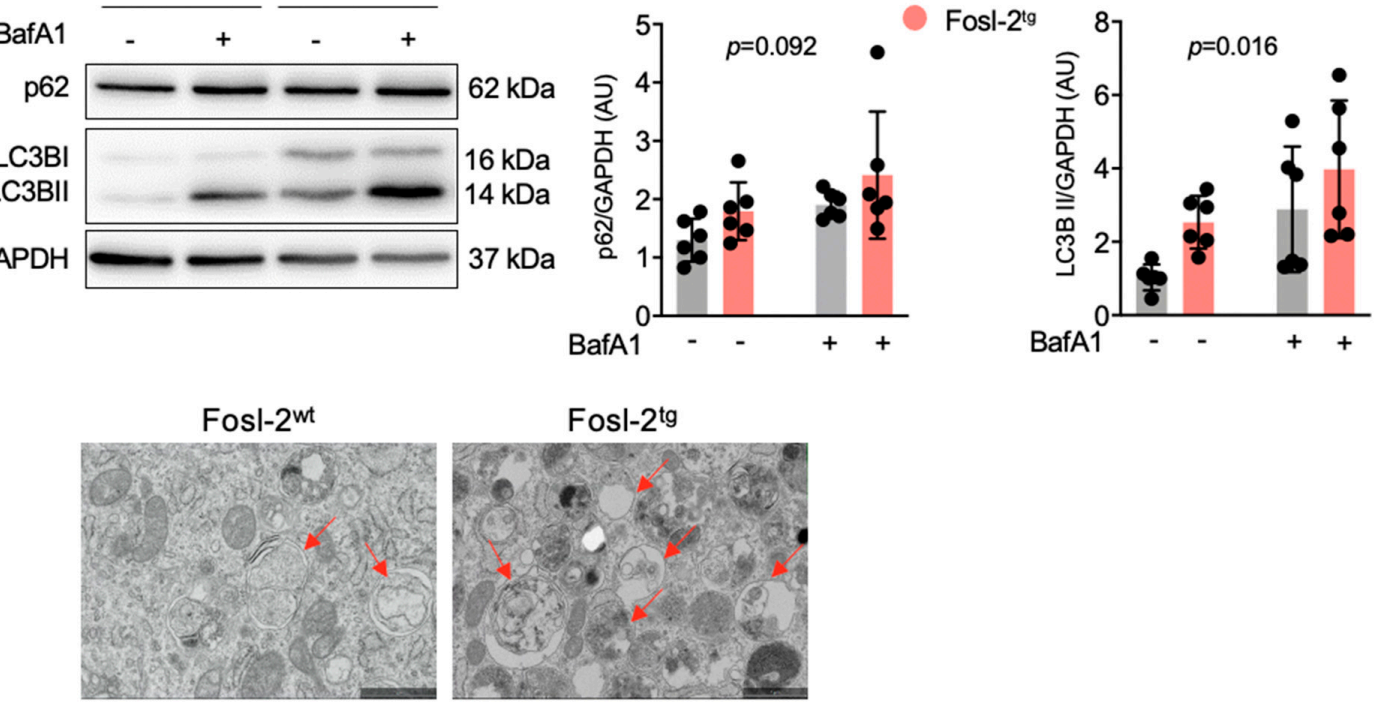

Fosl-2tg

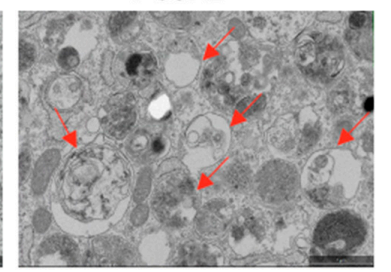

Figure 4. Increased autophagy in Fosl-2 ${ }^{\text {tg }}$ cardiac fibroblasts. (A) Representative immunohistochemistry of LC3B in heart sections of Fosl-2 ${ }^{\mathrm{wt}}$ (wild-type) and Fosl-2 ${ }^{\text {tg }}$ mice. Scale bar: $10 \mu \mathrm{m}$. (B) Representative immunoblots and corresponding densitometry of Fosl-2 ${ }^{\mathrm{wt}}$ and Fosl-2 ${ }^{\mathrm{tg}}$ cardiac fibroblasts under basal condition (Mann-Whitney $U$ test, $\mathrm{n}=8$ ). (C,D) Representative immunofluorescence staining of LC3B $\left(\mathbf{C}\right.$, red) and Atg5 (D, red) of Fosl-2 ${ }^{\mathrm{wt}}$ and Fosl- ${ }^{\text {tg }}$ cardiac fibroblasts cultured in $10 \%$ or $1 \%$ FBS with or without TGF- $\beta$ stimulation for $24 \mathrm{~h}(\mathrm{n}=3)$. Nuclei are stained with DAPI (blue). Scale bars: $10 \mu \mathrm{m}$. (E) Representative immunoblots and corresponding densitometry of Fosl-2 ${ }^{\mathrm{wt}}$ and Fosl-2 $2^{\mathrm{tg}}$ cardiac fibroblasts treated with or without BafA1 for $4 \mathrm{~h}$ (one-way ANOVA, $\mathrm{n}=7$ ). (F) Electron microscopy of Fosl-2 ${ }^{\mathrm{wt}}$ and Fosl-2 ${ }^{\mathrm{tg}}$ cardiac fibroblasts treated with BafA1 for $4 \mathrm{~h}(\mathrm{n}=3)$. Arrows indicate autophagosomes. Scale bars: $1 \mu \mathrm{m}$. 
A

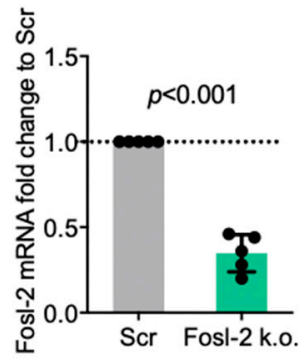

C

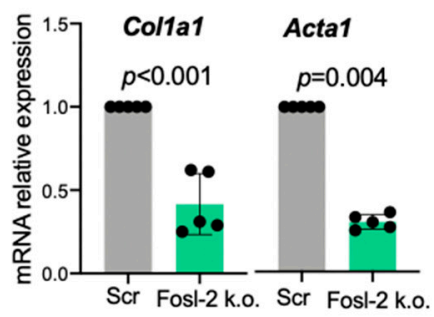

B
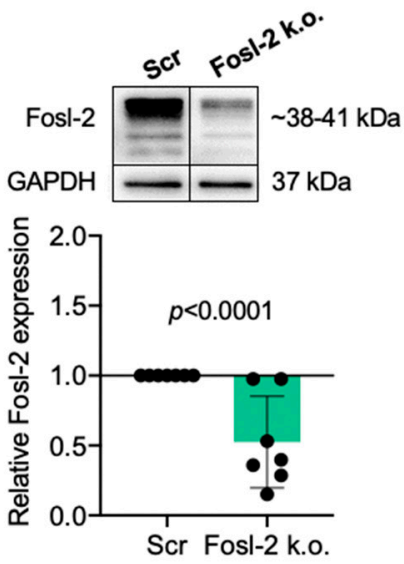

E
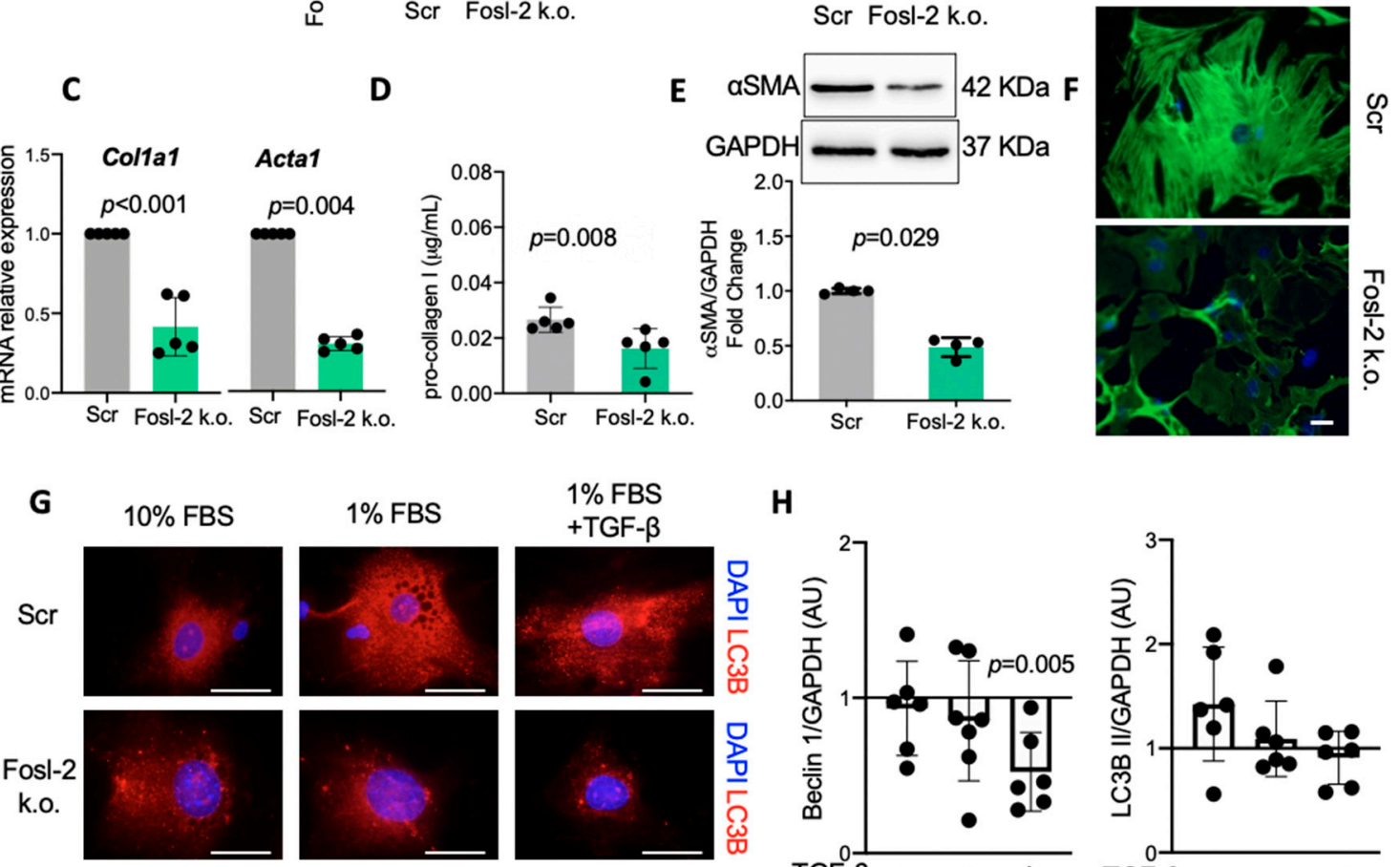

$1 \%$ FBS
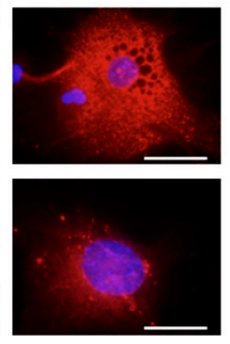

$1 \%$ FBS + TGF- $\beta$

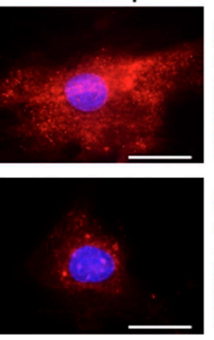

H

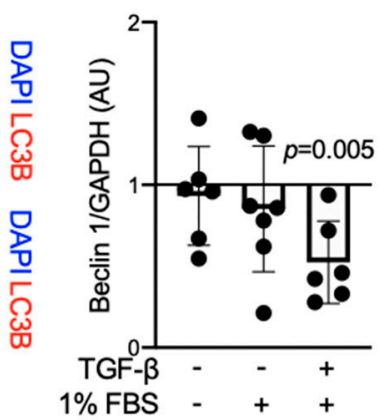

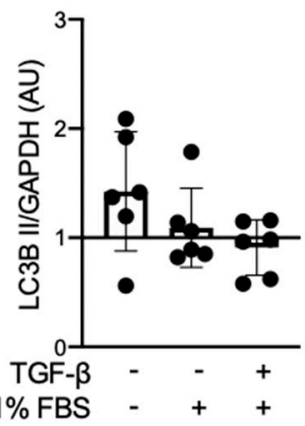

Figure 5. Silencing Fosl-2 suppresses autophagy in cardiac fibroblasts. Fosl-2 silencing was performed in cardiac fibroblasts using Fosl-2 antisense oligonucleotide GapmeR (Fosl-2 knockdown: k.o.) and was compared to scrambled control (Scr). Cells were cultured in starvation medium (1\% FBS), unless otherwise indicated. (A) Fosl2 gene expression ( $\mathrm{n}=5$, Mann-Whitney $U$ test), (B) representative immunoblots and densitometric analysis of Fosl-2 protein levels ( $\mathrm{n}=7$, Mann-Whitney $U$ test), (C) expression of genes encoding $\alpha \mathrm{SMA}$ (Acta2) and type I collagen (Col1a1) compared to Scr control ( $\mathrm{n}=5$, Mann-Whitney $U$ test). (D) pro-collagen I levels in supernatants $(n=5$, unpaired $t$-test), (E) representative immunoblots and densitometric analysis of $\alpha$ SMA protein levels ( $n=4$, Mann-Whitney $U$ test). (F) Representative immunofluorescence staining of $\alpha$ SMA $(\mathrm{n}=4$, nuclei in blue are stained with DAPI, scale bars: $10 \mu \mathrm{m}),(\mathrm{G})$ representative immunofluorescence staining of LC3B ( $n=5$, TGF- $\beta$ treatment $24 \mathrm{~h}$ ) and $(\mathbf{H})$ densitometry analysis of Becn1 and LC3B II protein levels presented in relation to the respective Scr controls ( $n=6$, Mann-Whitney $U$ test vs. Scr control). 
A

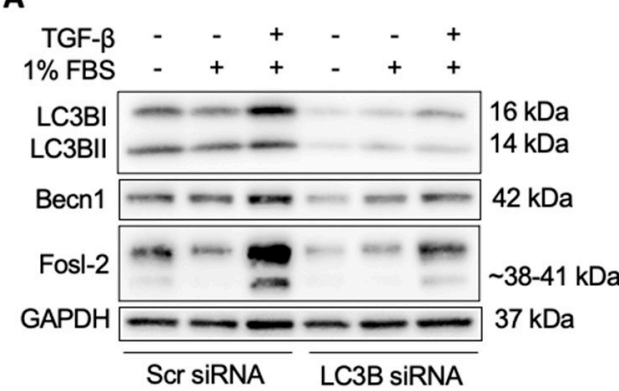

$\square$ Scr siRNA $\square$ LC3B siRNA
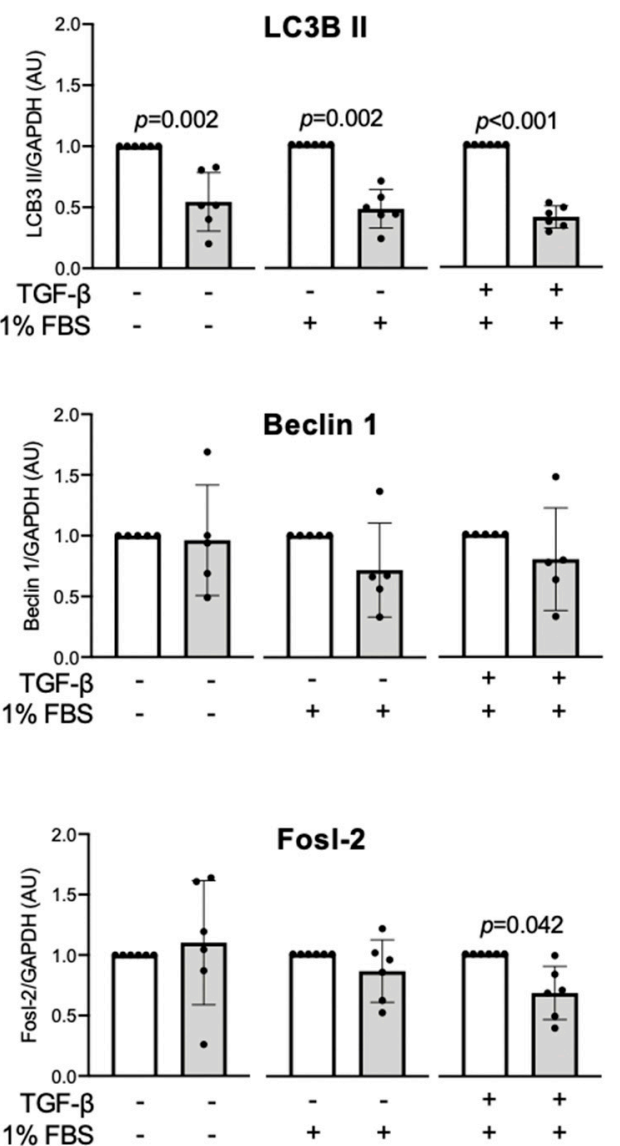

B

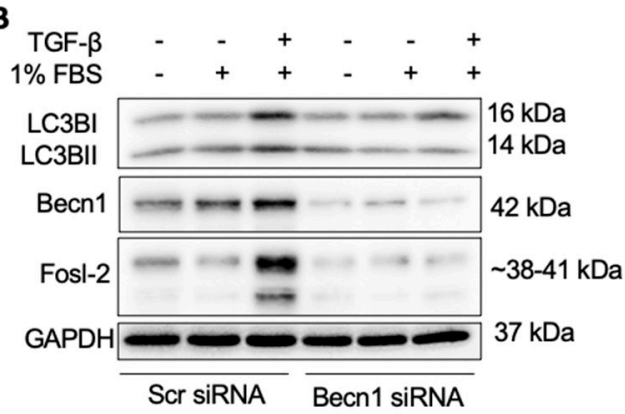

Scr siRNA $\square$ Becn1 siRNA

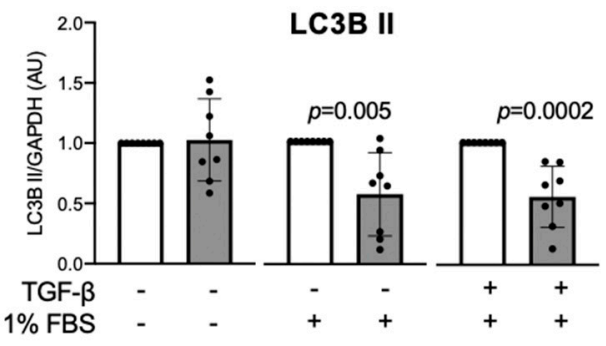

Beclin 1
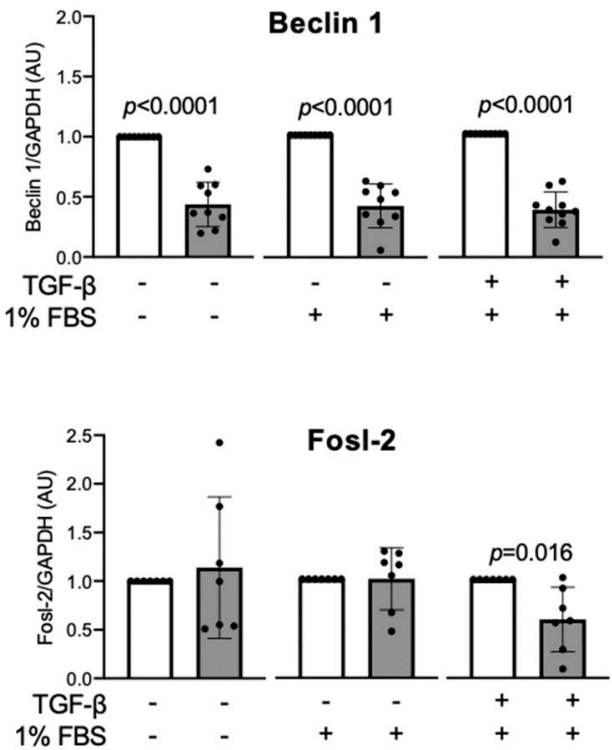

Figure 6. Autophagy regulates Fosl-2 in cardiac fibroblasts. LC3B and Beclin-1 silencing were performed in cardiac fibroblasts using the respective siRNAs that were compared to scrambled control (Scr). Cells were treated with medium containing $1 \%$ FBS and TGF- $\beta$ for $24 \mathrm{~h}$. Representative immunoblots and corresponding densitometry analysis of LC3B II, Beclin-1 and Fosl-2 protein levels following LC3B (A) or Beclin-1 (B, Becn1) silencing. Data are compared to the respective Scr control ( $n=5-9$, Mann-Whitney $U$ test vs. Scr control). 

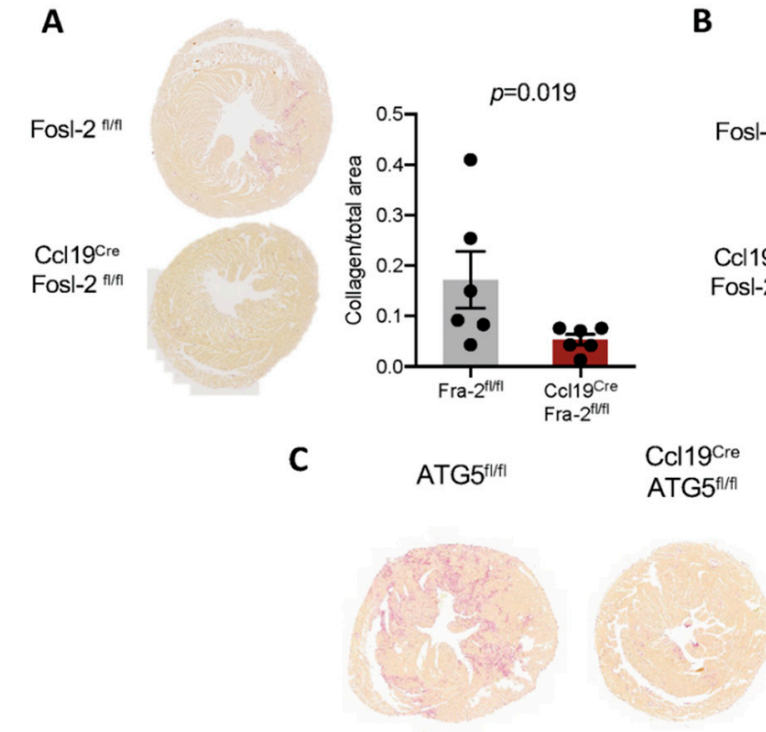

B

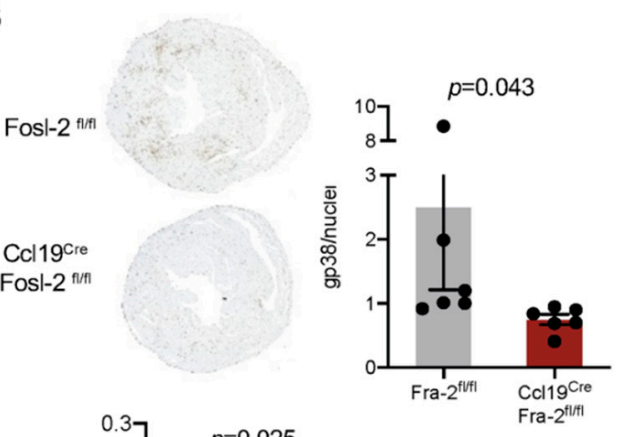

D
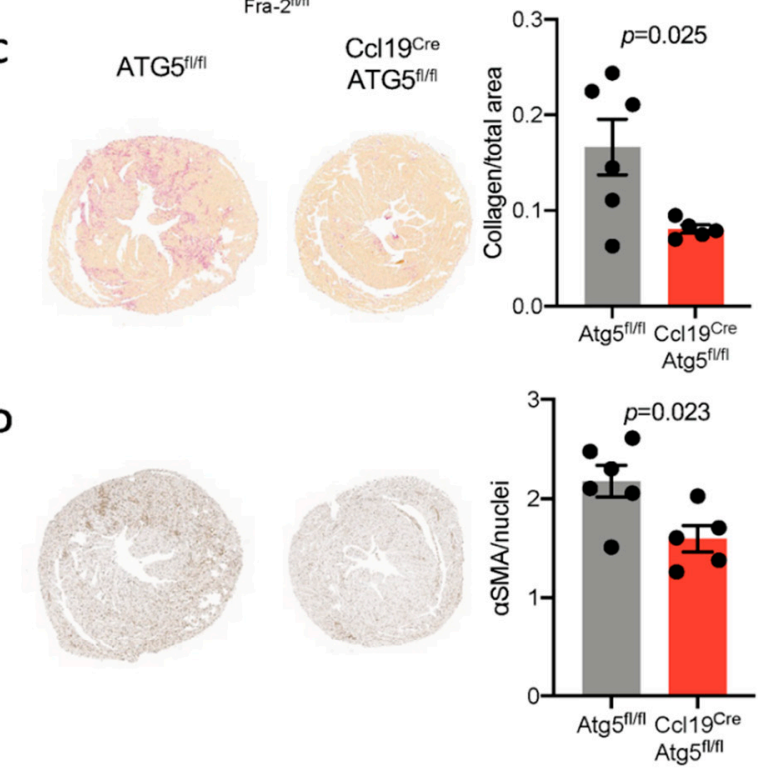

E

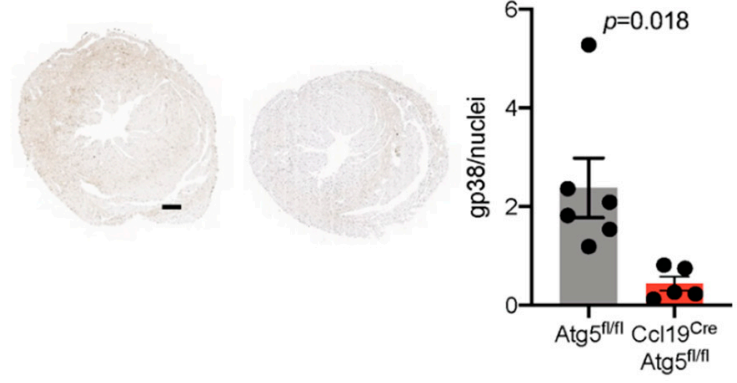

Figure 7. Fibroblast-specific deletion of Fosl-2 or Atg5 protects from angiotensin II-induced cardiac fibrosis. (A,B) Representative pictures and corresponding quantification of Sirius red indicating collagen deposition (A) and gp38 (podoplanin) immunopositive cells (B) of myocardial sections from Fosl- $2^{\mathrm{fl} / \mathrm{fl}}$ (control) mice and Ccl19 ${ }^{\text {Cre }}$ Fosl-2 ${ }^{\mathrm{fl} / \mathrm{fl}}$ mice infused with angiotensin II for 3 weeks ( $n=6$, Mann-Whitney $U$ test). (C-E) Representative pictures and corresponding quantification of Sirius red (C), $\alpha$ SMA (D) and gp38 immunopositive cells (E) of myocardial sections from Atgf5 $5^{\text {fl } / \mathrm{fl}}$ (control) mice and $\mathrm{Ccl19}{ }^{\mathrm{Cre}} \mathrm{Atg} 5^{\mathrm{fl} / \mathrm{fl}}$ mice infused with angiotensin II for 3 weeks ( $=5-6$, Mann-Whitney $U$ test). Scale bar for (A-E) (shown in $\mathbf{E}): 500 \mu \mathrm{m}$.

\section{Discussion}

Cardiac fibrogenesis and pathological tissue remodeling represent key disease progressing processes in non-ischemic heart disease, but the exact cellular and molecular mechanisms remain elusive. Here, we demonstrated a novel mechanism, by which the TGF- $\beta$-Fosl- 2 axis regulated profibrotic changes in cardiac fibroblasts by activating autophagocytosis. Previous studies have already shown the significance of autophagy in promoting fibrotic processes in multiple organs including skin [25], lung [26], liver [27], kidney [28] and heart [9-11]. It should be noted that in the heart, autophagocytosis might also be involved in antifibrotic and cardioprotective processes [8,12,13]. Activation of autophagocytosis is not limited to fibrotic processes but represents rather a com- 
mon mechanism in many pathophysiological processes in the body. Autophagy has been also implicated in pathophysiology of inflammatory [29] and neurodegenerative diseases [30-33], cancer [34,35] and during infections [36]. Previous studies in animal models addressed the effects of systemic or cardiomyocyte-specific deregulation of autophagy in the heart $[8,37,38]$, whereas in this work, we specifically focused on the role of autophagy in cardiac fibroblasts. We observed that fibroblast-specific deletion of the autophagic gene Atg5 effectively reduced cardiac fibrosis in a mouse model of cardiac hypertrophy. In line with our data, knock-out of autophagy activator peroxisome proliferator-activated receptor gamma coactivator $-1 \alpha$ in fibroblasts prevented development of skin fibrosis in a mouse model of systemic sclerosis [25]. The profibrotic role of autophagy in fibroblasts was further supported by in vitro data. In particular, autophagy enhanced TGF- $\beta$-mediated conversion of cardiac fibroblasts into myofibroblast, which is in accordance with previously published results [16,17]. Similarly, in dermal fibroblasts, starvation-induced autophagy also triggered myofibroblast differentiation and enhanced production of profibrotic connective tissue growth factor [15]. Autophagy-mediated degradation of cytoplasmic components is a crucial step during cell differentiation and in phenotypic transformation [39]. This could explain the importance of autophagy in the switch of quiescent fibroblast into pathogenic myofibroblast phenotype. It should be noted that the role of autophagy in fibrosis might be more complex. It has been postulated that active autophagocytosis might prevent overproduction of misfolded collagens and other extracellular matrix proteins $[40,41]$. It is possible that these antifibrotic processes occur in chronic fibrosis and contribute to the fibrotic phenotype over a long period of time only. Our models, instead, reflected early fibrogenesis rather than established fibrosis. Noteworthy, we observed a functional contribution of autophagy to fibrosis in both mouse and human cells. This is not surprising, because autophagocytosis is a highly conserved evolutionary process and its involvement in common biological processes, like fibrosis, should be maintained across the species. A growing body of evidence indicates that autophagy is regulated at a transcriptional level. Transcription factor EB (TFEB), E2 transcription factor 1 (E2F1) and forkhead box O3 (FOXO) represent examples of autophagy inducers, whereas zinc finger with KRAB and SCAN domains 3 (ZKSCAN3) has been recognized as a master repressor of autophagy [42]. Furthermore, tumor protein p53 (p53) and nuclear factor kappa-light-chain-enhancer of activated B cells $(\mathrm{NF}-\mathrm{kB})$ pathways have also been implicated in regulation of autophagy [42]. In addition to known molecular regulators, our study identified Fosl-2 transcription factor as a novel direct activator of autophagy. Fosl-2 has been shown to regulate profibrotic effects of TGF- $\beta$ in dermal fibroblasts of patients with systemic sclerosis and in mouse models of scleroderma [43], but its role in the regulation of autophagy has not been acknowledged until now. In line with our results, a pro-autophagic role was also demonstrated for another member of the AP-1 family, c-Jun. Published data demonstrated that c-Jun was involved in transcriptional regulation of LC3 and Beclin-1 [44], however other data indicated that c-Jun could play a repressive role in autophagy [45]. Of note, our data showed that complete blockade of autophagy with BafA1 suppressed Fosl-2 in cardiac fibroblasts, suggesting a feedback loop mechanism. In case of Beclin-1 and LC3B silencing, a downregulation of Fosl-2 was detected only under profibrotic conditions (+TGF- $\beta$ ). These results could be explained by the need to activate autophagy by TGF- $\beta$. Alternatively, incomplete silencing (about 50\%) of these pro-autophagic proteins may cause only partial suppression of autophagocytosis. All these data encourage us to postulate that a positive feedback loop between autophagy and Fosl-2 represents an important molecular mechanism in TGF- $\beta$-mediated fibrotic response of cardiac fibroblasts. Targeting this mechanism might represent a new strategy for treatment of fibrotic heart disease.

There are, however, certain concerns regarding benefits of systemic blockade of autophagocytosis, as this process plays an important role in cardiac homeostasis. In fact, clinical data demonstrated that pharmacological autophagy inhibitors chloroquine and hydroxychloroquine could cause cardiac complications in humans [46]. However, it should be noted that chloroquine and hydroxychloroquine are not autophagy-specific drugs and 
activate a significant number of off-target mechanisms [47]. It seems that targeting of Fosl-2 in specific cell types, rather than autophagy, might represent a more promising strategy in the treatment of fibrotic heart disease. Inhibition of Fosl-2 could suppress not only fibrotic processes, but also autoimmune responses [22,48].

\section{Materials and Methods}

\subsection{Animal Models}

Mice overexpressing Fosl-2 (Fosl-2 ${ }^{\mathrm{tg}}$ ) were obtained from Sanofi Pharmaceuticals, CA, USA, and backcrossed with C57Bl/ 6 mice (Charles Rivers) for at least 10 generations. A vector containing the murine Fosl-2 gene (Exons 1 to 4, corresponding introns, and truncated untranslated regions (UTRs) under the control of the major histocompatibility complex (MHCI) promotor $\mathrm{H} 2 \mathrm{~Kb}$ was randomly inserted into the genome [22]. Wildtype $\left(\right.$ Fosl- $\left.2^{\mathrm{wt}}\right)$ littermates were used as controls. Genotype was confirmed by enhanced green fluorescent protein (EGFP) expression in blood samples. Fosl- ${ }^{\mathrm{fl} / \mathrm{fl}}$ mice [23] were obtained from Dr. Aline Bozec (University of Erlangen, Germany) and rederivated by embryo transfer. Ccl19 ${ }^{\mathrm{Cre}}$ mice [49] were generated by Dr. Burkhard Ludewig (Cantonal Hospital St. Gallen, Switzerland). Ccl19 ${ }^{\mathrm{Cre}}$ Fosl- $2^{\mathrm{fl} / \mathrm{fl}}$ mice were generated by crossing Fosl-2 ${ }^{\mathrm{fl} / \mathrm{fl}}$ females and Ccl19 ${ }^{\mathrm{Cre}}$ males for at least 2 generations in order to obtain floxed Fosl-2 on both alleles. Atg $5^{\mathrm{fl} / \mathrm{fl}}$ mice [50] were kindly provided by Dr. Noboru Mizushima. $\mathrm{Ccl} 19^{\mathrm{Cre}} \mathrm{Atg} 5^{\mathrm{fl} / \mathrm{fl}}$ mice were generated by crossing $\mathrm{Atg} 5^{\mathrm{fl} / \mathrm{fl}}$ females and $\mathrm{C} \mathrm{Cl} 19^{\mathrm{Cre}}$ males for at least 2 generations in order to obtain floxed Atg 5 on both alleles. Animal experiments were performed in accordance with the Swiss federal law under the ethical approval ZH007/2010 (25.07.2019) and with the Guide for the Care and Use of Laboratory Animals, published by the US National Institutes of Health (NIH Publication, 8th Edition, 2011). Cantonal Veterinary Office Zurich approved all animal experiments.

\subsection{Isolation and Culture of Cardiac Fibroblasts}

Cardiac fibroblasts were isolated from Fosl- $2^{\text {wt }}$ and Fosl-2 ${ }^{\text {tg }}$ mice as previously described [18]. Briefly, mouse hearts were perfused with cold PBS, harvested mechanically and enzymatically digested by using magnetic beads in $0.025 \mathrm{mg} / \mathrm{mL}$ of Liberase (Collagenase I and II, Roche, Basel, Switzerland) solution in pure Dulbecco's modified Eagle's medium (DMEM) high glucose (Gibco) for $45 \mathrm{~min}$ at $37^{\circ} \mathrm{C}$. To inactivate Liberase activity, an equal amount of $10 \%$ fetal bovine serum (FBS, Gibco, Basel, Switzerland) in DMEM was added to the disintegrated tissues. The suspension was then filtered through a $70 \mu \mathrm{m}$ cell strainer and centrifuged at $55 \mathrm{~g}$ for $2 \mathrm{~min}$. Supernatants were further filtered through $40 \mu \mathrm{m}$ cell strainers and centrifuged at $490 \mathrm{~g}$ for $4 \mathrm{~min}$. Cell suspension was stained with anti-gp38-APC antibody (BioLegend, Clone: 8.1.1, London, United Kingdom) in fluorescence-activated cell sorting (FACS) buffer for $30 \mathrm{~min}$ at $4{ }^{\circ} \mathrm{C}$, washed with FACS Buffer, centrifuged and incubated with magnetic anti-APC-microbeads (Miltenyi Biotec, Bergisch Gladbach, Deutschland) for $30 \mathrm{~min}$ at $4{ }^{\circ} \mathrm{C}$. After further washing with FACS buffer, cells were sorted by an autoMACS Pro Separator (Miltenyi Biotec). Cells were plated and cultured in DMEM high glucose containing 20\% FBS, $50 \mathrm{U} / \mathrm{mL}$ penicillin, $50 \mu \mathrm{g} / \mathrm{mL}$ streptomycin (Gibco) and $50 \mathrm{mM}$ 2-mercaptoethanol (Gibco). Fetal human cardiac fibroblasts were purchased from Sigma-Aldrich, and cells of passages 10-15 were cultured as described above. In selected experiments, cells were starved substituting the culturing medium with medium containing 1\% FBS, pre-treated with Bafilomycin A1 (BafA1; $50 \mathrm{nM}$, Sigma-Aldrich, Basel, Switzerland) for $4 \mathrm{~h}$ or stimulated with $10 \mathrm{ng} / \mathrm{mL}$ recombinant TGF- $\beta$ (Peprotech, London, United Kingdom).

\subsection{Human Endomyocardial Biopsies}

Human endomyocardial biopsies (hEMBs) were obtained from patients with systemic sclerosis and inflammatory dilated cardiomyopathy (iDCM, Table 1) and patients with healed myocarditis (Table 2), which were used as controls. Samples were provided by the University Hospital Tubingen, Germany. The Ethik-Kommission der Medizinischen 
Fakultät des Universitätsklinikums Tubingen gave the approval to investigate endomyocardial biopsies and heart tissue which were sent for diagnostic reasons by histological and immunohistological investigations for further pathogenetic research. Approval number: 138/2004V (approval date: 9 April 2018). The experiments with re-usage of human material were approved by Swissethics (BASEC-Nr. 2019-00058, approved on 4 April 2019), and were performed in conformity with the principles outlined in the Declaration of Helsinki. The informed written consent was given prior to the inclusion of subjects in the study.

Table 1. Characteristic of iDCM patients and hEMBs.

\begin{tabular}{|c|c|}
\hline Patient Characteristic & All EMBs $(n=9)$ \\
\hline Age (mean \pm SD years) & $56.5 \pm 10.5$ \\
\hline $\begin{array}{c}\text { Gender } \\
\text { Female }(\mathrm{n} / \mathrm{N}, \%)\end{array}$ & $4 / 9(44.4 \%)$ \\
\hline Interstitial fibrosis (n/N, \%) & $9 / 9(100 \%)$ \\
\hline Vasculitis (n/N, \%) & $2 / 9(22.2 \%)$ \\
\hline Hypertrophy of myocytes (n/N, \%) & $2 / 9(22.2 \%)$ \\
\hline Ejection fraction $(\mathrm{EF})<50 \%(\mathrm{n} / \mathrm{N}, \%)$ & $4 / 6(66.7 \%)$ \\
\hline $\mathrm{EF}>50 \%(\mathrm{n} / \mathrm{N}, \%)$ & $2 / 6(33.3 \%)$ \\
\hline HLA-DR $\alpha^{+}$macrophages $(\mathrm{n} / \mathrm{N}, \%)$ & $9 / 9(100 \%)$ \\
\hline $\mathrm{CD} 8^{+}$macrophages $(\mathrm{n} / \mathrm{N}, \%)$ & $8 / 9(88.9 \%)$ \\
\hline $\mathrm{CD}^{+} \mathrm{T}$ cells $\left(>7 / \mathrm{mm}^{2}\right)(\mathrm{n} / \mathrm{N}, \%)$ & $8 / 9(88.9 \%)$ \\
\hline$\alpha \mathrm{SMA}^{+}$proliferating myofibroblasts $(\mathrm{n} / \mathrm{N}, \%)$ & $6 / 9(66.7 \%)$ \\
\hline HLA-DR $\alpha^{+}$endothelial capillaries (n/N, \%) & $4 / 9(44.4 \%)$ \\
\hline Virus negativity (n/N, \%) & $9 / 9(100 \%)$ \\
\hline Active lymphocytic myocarditis (n/N, \%) & $1 / 9(11.1 \%)$ \\
\hline Eosinophilic myocarditis (n/N, \%) & $0 / 9(0 \%)$ \\
\hline Subacute/chronic myocarditis (n/N, \%) & $1 / 9(11.1 \%)$ \\
\hline AV Block III (n/N, \%) & $1 / 9(11.1 \%)$ \\
\hline
\end{tabular}

Table 2. Characteristic of patients with healed or not confirmed myocarditis.

\begin{tabular}{cc}
\hline Patient Characteristic & All EMBs (n = 6) \\
\hline Age (mean \pm SD years) & $39.7 \pm 19.2$ \\
\hline $\begin{array}{c}\text { Gender } \\
\text { Female (n/N, \%) }\end{array}$ & $1 / 6(16.7 \%)$ \\
\hline Interstitial fibrosis (n/N, \%) & $0 / 6(0 \%)$ \\
\hline Active or chronic myocarditis (n/N, \%) & $0 / 6(0 \%)$ \\
\hline $\mathrm{EF}<50 \%(\mathrm{n} / \mathrm{N}, \%)$ & $0 / 6(0 \%)$ \\
\hline $\mathrm{EF}>50 \%(\mathrm{n} / \mathrm{N}, \%)$ & $6 / 6(100 \%)$ \\
\hline
\end{tabular}

\subsection{Gene Silencing}

Cells were seeded in 6-well plates $(180,000$ cells /well) or 8-chamber slides $(15,000$ cells/well) and transfected with GapmeR or siRNA (Table 3) or the respective controls. Transient transfection was performed by $6 \mathrm{~h}$ incubation with Lipofectamine 2000 (Thermo Fisher Scientific) prior to treatments. 
Table 3. Transfection reagents for gene silencing.

\begin{tabular}{cccc}
\hline Target & Transfection Reagent & Conc. & Company \\
\hline Fosl-2 & Antisense longRNA (LNA) GapmeRs & $150 \mathrm{nM}$ & Qiagen \\
\hline Neg. control & Antisense LNA GapmeR Control & $150 \mathrm{nM}$ & Qiagen \\
\hline LC3B & ON-TARGETplus Mouse Map1lc3b & $25 \mathrm{nM}$ & Dharmacon \\
\hline siRNA & ON-TARGETplus Mouse Beclin 1 siRNA & $\mathrm{nM}$ & Dharmacon \\
\hline Neg. control & ON-TARGETplus Non-targeting Pool & 25 nM & Dharmacon \\
\hline
\end{tabular}

\subsection{Contraction Assay}

Fibroblast contraction in collagen gel was performed with the cell contraction assay kit (Cell Biolabs, Heidelberg, Germany) according to manufacturer's instructions. Pictures were taken at day (d) 0, d3 and d4 using the Fusion Fx (Vilber, Eberhardzell, Germany). The areas of gels were computed with ImageJ $1.52 \mathrm{a}$.

\subsection{Immunoblotting}

Cells were trypsinized and proteins were extracted using radioimmunoprecipitation assay buffer (RIPA) Buffer (Sigma-Aldrich) complemented with protease inhibitor cocktail (cOmplete ULTRA tablets, Roche) and phosphatase inhibitors (PhosSTOP, Roche). Bicinchoninic acid assay (BCA) was used for protein quantification. 20-30 $\mu$ g of proteins was used for immunoblotting analyses. Proteins were transferred on nitrocellulose membranes by wet-transfer method and incubated for $45 \mathrm{~min}$ in blocking solution (5\% milk, Becton Dickinson, Allschwil, Switzerland) in tris-buffered saline and 0.05\% Tween-20 (TBST), followed by an overnight incubation at $4{ }^{\circ} \mathrm{C}$ with primary antibodies (Table 4 ) and secondary antibodies conjugated with horseradish peroxidase (HRP) for $45 \mathrm{~min}$. When needed, mild and harsh stripping were performed according to the protocol from Abcam.

Table 4. List of used antibodies.

\begin{tabular}{|c|c|c|c|c|}
\hline Target & Clone & REF & Dilution & Company \\
\hline Anti-Atg 5 & EPR1755(2) & ab108327 & 1:1000 (WB) & Abcam \\
\hline Anti-Beclin 1 & EPR20473 & ab210498 & 1:1000 (WB) & Abcam \\
\hline Anti-LC3B & polyclonal & 2775 & 1:1000 (WB) & Cell Signaling \\
\hline Anti- $\alpha$ SMA & $1 \mathrm{~A} 4$ & A2547 & 1:5000 (WB) & Sigma \\
\hline Anti-Fosl-2 & REY146C & MABS1261 & 1:500 (WB) & $\begin{array}{l}\text { EMD Millipore } \\
\text { Corp. }\end{array}$ \\
\hline Anti-GAPDH & $14 \mathrm{C} 10$ & 2118 & 1:5000 (WB) & Cell Signaling \\
\hline Ter119 (PE) & TER-119 & $(12-5921-81)$ & 1:300 (FACS) & eBioscience \\
\hline CD45 (PE) & 30-F11 & $(12-0451-82)$ & 1:300 (FACS) & eBioscience \\
\hline CD31 (PE) & 390 & $(12-0311-81)$ & 1:300 (FACS) & eBioscience \\
\hline gp38 (APC) & 8.1 .1 & (127409) & 1:100 (FACS) & BioLegend \\
\hline$\alpha$ SMA & $1 \mathrm{~A} 4$ & (A2547) & $1: 100$ (IF) & Sigma \\
\hline$\alpha \mathrm{SMA}$ & GR3252482-2 & (ab5694) & 1:100 (IHC) & Abcam \\
\hline $\begin{array}{c}\text { Anti-p44/p42 } \\
\text { MAPK } \\
\text { (ERK1/2) }\end{array}$ & 137F5 & $4695 \mathrm{~T}$ & 1:1000 (WB) & Cell Signaling \\
\hline Anti-p-TAK1 & S412 & 9339S & 1:1000 (WB) & Cell Signaling \\
\hline
\end{tabular}


Table 4. Cont.

\begin{tabular}{ccccc}
\hline Target & Clone & REF & Dilution & Company \\
\hline Anti-TAK1 & polyclonal & $4505 S$ & $1: 1000(\mathrm{WB})$ & Cell Signaling \\
\hline $\begin{array}{c}\text { Anti-p-Smad2 } \\
\text { (S465/467) }\end{array}$ & 138D4 & $3108 \mathrm{~S}$ & $1: 1000(\mathrm{WB})$ & Cell Signaling \\
\hline Anti-Smad2 & D43B4 & $5339 \mathrm{~S}$ & $1: 1000(\mathrm{WB})$ & Cell Signaling \\
\hline Anti-p-mTOR & S2448 & $2971 S$ & $1: 1000(\mathrm{WB})$ & Cell Signaling \\
\hline Anti-mTOR & 7C10 & $2983 S$ & $1: 1000(\mathrm{WB})$ & Cell Signaling \\
\hline $\begin{array}{c}\text { Anti- } \\
\text { SQSTM1/p62 }\end{array}$ & GR3285981-1 & ab56416 & $1: 1000(\mathrm{WB})$ & Abcam \\
\hline
\end{tabular}

Enhanced chemiluminescent substrate was used for the development on the Fusion Fx (Vilber). Densitometric analyses were conducted with ImageJ 1.52 a (https:/ / imagej.net/ Welcome). Fold changes were computed after normalization to glyceraldehyde 3-phosphate dehydrogenase (GAPDH).

\subsection{Immunofluorescence Staining of Cultured Cells}

Per well, 15,000 cells were seeded in glass 8-chamber slides (Milian, Boswil, Switzerland). For LC3B, Atg5 and Beclin-1 detection, cells were fixed in ice-cold $100 \%$ methanol for $10 \mathrm{~min}$ at $-20^{\circ} \mathrm{C}$ and permeabilized for $15 \mathrm{~min}$ with $0.1 \%$ TritonX-100 (Sigma-Aldrich). For $\alpha$-smooth muscle actin ( $\alpha$ SMA) detection, cells were fixed in ice-cold methanol:acetone in ratio 7:3 (both Sigma-Aldrich) for $10 \mathrm{~min}$ at $-20{ }^{\circ} \mathrm{C}$. Blocking was performed for $20 \mathrm{~min}$ with $10 \%$ FBS in PBS. Next, slides were incubated with the primary antibody (Table 3 ) diluted in PBS for $1 \mathrm{~h}$ at room temperature, followed by incubation with AlexaFluor 546 goat anti-rabbit IgG antibody (1:400, polyclonal, Invitrogen) or AlexaFluor 546 goat antimouse IgG antibody (1:400, polyclonal, Invitrogen) for $45 \mathrm{~min}$ at room temperature in the dark. Mounting medium (Dako, Baar, Switzerland) complemented with nuclear staining (4',6-diamidino-2-phenylindole (DAPI $1 \mu \mathrm{g} / \mathrm{mL}$, Roche)) were used to apply the cover slip to each slide. Images were acquired with an Olympus BX53 microscope equipped with a DP80 camera and edited with Image $1.52 \mathrm{a}$.

\subsection{ELISA}

Pro-collagen I levels in cell culture supernatants were measured according to the manufacturer's protocol using mouse pro-collagen I alpha 1 ELISA (Abcam, Cambridge, United Kingdom) and human pro-collagen I alpha 1 ELISA (R\&D Systems, London, United Kingdom).

\subsection{Proliferation and Apoptosis Assays}

Cells were seeded in 96-well plates (20,000 cells/well): $24 \mathrm{~h}$ after seeding, cells were pretreated with BafA1 for $4 \mathrm{~h}$, and after that, bromodeoxyuridine (BrdU, Sigma-Aldrich) was added to the culture medium for the next $24 \mathrm{~h}$. Proliferation was measured as BrdU incorporation using the colorimetric cell proliferation BrdU ELISA assay (Roche) according to the manufacturer's protocol. Apoptosis was analyzed by measuring caspase $3 / 7$ activity using the Caspase-Glo 3/7 assay (Promega, Dubendort, Switzerland) following the manufacturer's protocol. BrdU absorbances and Cas3/7 luminescence were measured with the Synergy HT microplate reader (BioTek, Zurich, Switzerland). Each sample was measured in quadruplicates.

\subsection{Electron Microscopy}

Cells were grown in their standard cell culture medium on $12 \mathrm{~mm}$ cover glasses treated with $L$-polylysine. Cells were sequentially fixed with $2.5 \%$ glutaraldehyde in $0.1 \mathrm{M}$ sodium cacodylate buffer ( $\mathrm{pH} 7.35$, pre-warmed to $37^{\circ} \mathrm{C}$ ) for $1 \mathrm{~h}$, with $1 \% \mathrm{OsO}_{4}$ for $1 \mathrm{~h}$ in $0.1 \mathrm{M}$ 
cacodylate buffer at $0{ }^{\circ} \mathrm{C}$, and $2 \%$ aqueous uranyl acetate for $1 \mathrm{~h}$ at $4{ }^{\circ} \mathrm{C}$. Samples were then dehydrated in an ethanol series and embedded in Epon/Araldite (Sigma-Aldrich). Ultrathin $(70 \mathrm{~nm})$ sections were post-stained with lead citrate and examined with a Talos 120 transmission electron microscope at an acceleration voltage of $120 \mathrm{KV}$ using a Ceta digital camera and the MAPS software package (Thermo Fisher Scientific).

\subsection{Angiotensin II-Induced Cardiac Hypertrophy Mouse Model}

ALZET Osmotic minipump Model 2004 (pumping rate of $0.25 \mu \mathrm{L} / \mathrm{h}$ ) were filled with $250 \mu \mathrm{L}$ of $12.5 \mathrm{mg} / \mathrm{mL}$ angiotensin II (Bachem, Bubendorf, Switzerland) or $\mathrm{NaCl}$ and equilibrated in $\mathrm{NaCl}$ for 3 days at $37^{\circ} \mathrm{C}$ and were implanted in 8- to 12-week-old mice. For implantation, mice received $0.05 \mathrm{mg} / \mathrm{kg}$ finadyne (Flunixin-Meglumin, Zurich, Switzerland), after which they were anesthetized by inhalation of $5 \%$ isoflurane, decreased to $1.5-2 \%$ to maintain anesthesia. During surgery, mice were placed on a heating pad and cream (Vitamin A, Baush \& Lomb, Zurich, Switzerland) was applied on eyes. After shaving the upper back of the mouse and disinfecting by Betadine (Povidone-iodine), a $\sim 1 \mathrm{~cm}$ incision was made to implant the minipump. The wound was closed with clips and mice were allowed to recover under a red-light lamp. Novaminsulfon (Metamizol, 200$400 \mathrm{mg} / \mathrm{kg}$ /day) was administrated in drinking water for 3 days after surgery, in order to keep pain at the minimum level.

\subsection{Methods of Euthanasia}

Mice were euthanized with 2-3 L/min influx of carbon dioxide for $5 \mathrm{~min}$ into the cage. After cessation of breathing, animals were left in carbon dioxide for an additional $5 \mathrm{~min}$. To ensure death, animals were exsanguinated via intracardiac blood collection before tissue harvest.

\subsection{Immunohistochemistry}

Organs were fixed with $4 \%$ paraformaldehyde (PFA) for $12 \mathrm{~h}$ and paraffin-embedded. To detect collagen fibers, direct Red Sirius Red (Sigma-Aldrich) staining was used. Prior to immunohistochemistry, sections were boiled in citrate buffer $(10 \mathrm{mM}$ Citrate, $0.05 \%$ tween, $\mathrm{pH}=6$, Sigma-Aldrich) and further incubated at $95^{\circ} \mathrm{C}$ for $15 \mathrm{~min}$. Next, slides were incubated for $15 \mathrm{~min}$ in $3 \% \mathrm{H}_{2} \mathrm{O}_{2}$ solution to block endogenous peroxidases, followed by a blocking step for one hour in 10\% goat serum in Background Reducing Antibody Diluent (Dako). Avidin-Biotin Block kit (from Vector Laboratories, Servion, Switzerland) was used to block endogenous biotin. The primary antibody (Table 4) was incubated overnight at $4{ }^{\circ} \mathrm{C}$ followed by incubation with proper biotinylated secondary antibody (Vector Laboratories) for $30 \mathrm{~min}$ at room temperature. Sections were then incubated for $30 \mathrm{~min}$ with Vectastain Elite ABC solution (Vector Laboratories). Staining was developed using 3, 3 -diaminobenzidine (DAB, Vector Laboratories) followed by a counterstaining of nuclei for $1 \mathrm{~min}$ in Mayer's hematoxylin solution (J.T Baker, Zurich, Switzerland). Quantification was performed on 2 consecutive cardiac sections from each mouse. The entire slide was scanned using a Slidescanner Zeiss Axio Scan microscope. ImageJ software was used to quantify positive signals.

\subsection{Statistical Analysis}

Shapiro-Wilk's normality test was performed to evaluate the distribution of the data. Normally distributed data were analyzed by unpaired or paired two-tailed Student's $t$-test or one-way analysis of variance (ANOVA) followed by the Fisher's Least Significant Difference (LSD) post-hoc test, while nonparametric data were analyzed using the Mann-Whitney $U$ test. All analyses were performed with the GraphPad Prism 8 software. Differences were considered statistically significant for $p<0.05$.

Supplementary Materials: The following are available online at https:/ / www.mdpi.com/1422-0 067/22/4/1861/s1, Figure S1: Activation of autophagy process in human foetal cardiac fibroblasts (hfCFs), Figure S2: Co-activation of autophagy and TGF- $\beta$ signalling in mouse Fosl-2wt cardiac 
fibroblasts, Figure S3: Angiotensin (Ang) II-induced cardiac hypertrophy model, Figure S4: Characteristic of $\mathrm{Ccl} 19^{\mathrm{Cre}} \mathrm{Atg} 5^{\mathrm{fl} / \mathrm{fl}}$ and $\mathrm{Ccl} 19^{\mathrm{Cr}}$ Fosl-2 $2^{\mathrm{fl} / \mathrm{fl}}$ mice in cardiac hypertrophy model, The disclosure statement of Prof. O. Distler

Author Contributions: Conceptualization, G.K. and P.B.; methodology, J.S., M.S. and A.H.; software, J.S., M.S. and A.H.; validation, J.S., M.S., G.K. and A.H.; formal analysis, J.S., M.S., G.K. and A.H.; investigation, J.S., M.S., G.K. and P.B. and A.H.; resources, G.K., K.K. and B.L.; data curation, J.S., M.S., G.K. and A.H.; writing-original draft preparation, M.S., G.K. and P.B.; writing—review and editing, G.K., O.D. and P.B.; visualization, M.S., J.S. and G.K.; supervision, G.K.; project administration, G.K.; funding acquisition, G.K. All authors have read and agreed to the published version of the manuscript.

Funding: G.K. acknowledges support from the Swiss National Science Foundation (310030_152876/1; 310030_175663), Hartmann Muller Foundation, Theodor und Ida Herzog-Egli Foundation, Novartis Foundation, Swiss Life Foundation, Kunt und Senta Hermann Foundation, Hermann Klaus Foundation, Baugarten Foundation, Horten Foundation, 4-Taget Bayer Grant.

Institutional Review Board Statement: The study was conducted according to the guidelines of the Declaration of Helsinki and approved by the Ethik-Kommission der Medizinischen Fakultät des Universitätsklinikums Tubingen gave the approval to investigate endomyocardial biopsies and heart tissue which were sent for diagnostic reasons by histological and immunohistological investigations for further pathogenetic research. Approval number: 138/2004V (approval date: 9 April 2018). The experiments with re-usage of human material were approved by Swissethics (BASEC-Nr. 201900058, approved on 4 April 2019). Animal experiments were performed in accordance with the Swiss federal law under the ethical approval ZH007/2010 (25.07.2019) and with the Guide for the Care and Use of Laboratory Animals, published by the US National Institutes of Health (NIH Publication, 8th Edition, 2011). Cantonal Veterinary Office Zurich Switzerland approved all animal experiments.

Informed Consent Statement: Informed consent was obtained from all subjects involved in the study.

Data Availability Statement: Not applicable.

Acknowledgments: We thank Maria Comazzi-Fornallaz for excellent technical assistance, and Sophistolab and University of Zurich Center for Microscopy and Image Analysis for excellent service support.

Conflicts of Interest: The disclosure statement of Prof. O. Distler is available in the supplementary online materials.

\section{References}

1. Travers, J.G.; Kamal, F.A.; Robbins, J.; Yutzey, K.E.; Blaxall, B.C. Cardiac Fibrosis: The Fibroblast Awakens. Circ. Res. 2016, 118, 1021-1040. [CrossRef] [PubMed]

2. Kania, G.; Blyszczuk, P.; Eriksson, U. Mechanisms of Cardiac Fibrosis in Inflammatory Heart Disease. Trends Cardiovasc. Med. 2009, 19, 247-252. [CrossRef] [PubMed]

3. Yang, Z.; Klionsky, D.J. Mammalian autophagy: Core molecular machinery and signaling regulation. Curr. Opin. Cell Biol. 2010, 22, 124-131. [CrossRef] [PubMed]

4. Lee, Y.K.; Lee, J.A. Role of the mammalian ATG8/LC3 family in autophagy: Differential and compensatory roles in the spatiotemporal regulation of autophagy. BMB Rep. 2016, 49, 424-430. [CrossRef]

5. Abdellatif, M.; Sedej, S.; Carmona-Gutierrez, D.; Madeo, F.; Kroemer, G. Autophagy in Cardiovascular Aging. Circ. Res. 2018, 123, 803-824. [CrossRef] [PubMed]

6. Tanaka, Y.; Guhde, G.; Suter, A.; Eskelinen, E.-L.; Hartmann, D.H.; Lüllmann-Rauch, R.; Janssen, P.M.L.; Blanz, J.; Von Figura, K.; Saftig, P. Accumulation of autophagic vacuoles and cardiomyopathy in LAMP-2-deficient mice. Nat. Cell Biol. 2000, 406, 902-906. [CrossRef] [PubMed]

7. Zaglia, T.; Milan, G.; Ruhs, A.; Franzoso, M.; Bertaggia, E.; Pianca, N.; Carpi, A.; Carullo, P.; Pesce, P.; Sacerdoti, D.; et al. Atrogin-1 deficiency promotes cardiomyopathy and premature death via impaired au-tophagy. J. Clin. Invest. 2014, 124, 2410-2424. [CrossRef]

8. Nakai, A.; Yamaguchi, O.; Takeda, T.; Higuchi, Y.; Hikoso, S.; Taniike, M.; Omiya, S.; Mizote, I.; Matsumura, Y.; Asahi, M.; et al. The role of autophagy in cardiomyocytes in the basal state and in response to hemodynamic stress. Nat. Med. 2007, 13, 619-624. [CrossRef] [PubMed]

9. Zhu, H.; Tannous, P.; Johnstone, J.L.; Kong, Y.; Shelton, J.M.; Richardson, J.A.; Le, V.; Levine, B.; Rothermel, B.A.; Hill, J.A. Cardiac autophagy is a maladaptive response to hemodynamic stress. J. Clin. Investig. 2007, 117, 1782-1793. [CrossRef] [PubMed] 
10. Cao, D.J.; Wang, Z.V.; Battiprolu, P.K.; Jiang, N.; Morales, C.R.; Kong, Y.; Rothermel, B.A.; Gillette, T.G.; Hill, J.A. Histone deacetylase (HDAC) inhibitors attenuate cardiac hypertrophy by suppressing autophagy. Proc. Natl. Acad. Sci. USA 2011, 108, 4123-4128. [CrossRef]

11. Zhang, G.-S.; Yuan, X.; Xiao, Y.-C.; Zhang, G.-P.; Hou, N.; Wu, X.-Q.; Chen, W.-L.; Luo, J.-D. Chloroquine improves left ventricle diastolic function in streptozotocin-induced diabetic mice. Drug Des. Dev. Ther. 2016, 10, 2729-2737. [CrossRef] [PubMed]

12. Zhao, W.; Li, Y.; Jia, L.; Pan, L.; Li, H.; Du, J. Atg 5 deficiency-mediated mitophagy aggravates cardiac inflammation and injury in response to angiotensin II. Free Radic. Biol. Med. 2014, 69, 108-115. [CrossRef] [PubMed]

13. Tannous, P.; Zhu, H.; Johnstone, J.L.; Shelton, J.M.; Rajasekaran, N.S.; Benjamin, I.J.; Nguyen, L.; Gerard, R.D.; Levine, B.; Rothermel, B.A.; et al. Autophagy is an adaptive response in desmin-related cardiomyopathy. Proc. Natl. Acad. Sci. USA 2008, 105, 9745-9750. [CrossRef]

14. Wang, Z.V.; Ferdous, A.; Hill, J.A. Cardiomyocyte autophagy: Metabolic profit and loss. Heart Fail. Rev. 2013, 18, 585-594. [CrossRef] [PubMed]

15. Bernard, M.; Dieudé, M.; Yang, B.; Hamelin, K.; Underwood, K.; Hébert, M.-J. Autophagy fosters myofibroblast differentiation through MTORC2 activation and downstream upregulation of CTGF. Autophagy 2014, 10, 2193-2207. [CrossRef] [PubMed]

16. Ghavami, S.; Cunnington, R.H.; Gupta, S.; Yeganeh, B.; Filomeno, K.L.; Freed, D.H.; Chen, S.; Klonisch, T.; Halayko, A.J.; Ambrose, E.; et al. Autophagy is a regulator of TGF-beta1-induced fibrogenesis in primary human atrial myofibroblasts. Cell Death Dis. 2015, 6, e1696. [CrossRef] [PubMed]

17. Gupta, S.S.; Zeglinski, M.R.; Rattan, S.G.; Landry, N.M.; Ghavami, S.; Wigle, J.T.; Klonisch, T.; Halayko, A.J.; Dixon, I.M. Inhibition of au-tophagy inhibits the conversion of cardiac fibroblasts to cardiac myofibroblasts. Oncotarget 2016, 7, 78516-78531. [CrossRef]

18. Stellato, M.; Czepiel, M.; Distler, O.; Błyszczuk, P.; Kania, G. Identification and Isolation of Cardiac Fibroblasts From the Adult Mouse Heart Using Two-Color Flow Cytometry. Front. Cardiovasc. Med. 2019, 6, 105. [CrossRef] [PubMed]

19. Tkacz, K.; Rolski, F.; Czepiel, M.; Dzialo, E.; Siedlar, M.; Eriksson, U.; Kania, G.; Blyszczuk, P. Haploinsufficient Rock1(+/-) and Rock2(+/-) Mice Are Not Protected from Cardiac Inflammation and Postinflammatory Fibrosis in Experimental Autoimmune Myocarditis. Cells 2020, 9, 700. [CrossRef] [PubMed]

20. Ding, Y.; Kim, J.K.; Kim, S.I.; Na, H.J.; Jun, S.Y.; Lee, S.J.; Choi, M.E. TGF- $\beta 1$ protects against mesangial cell apoptosis via induction of autophagy. J. Biol. Chem. 2010, 285, 37909-37919. [CrossRef]

21. Dzialo, E.; Tkacz, K.; Blyszczuk, P. Crosstalk between the TGF-beta and WNT signalling pathways during cardiac fibrogenesis. Acta Biochim. Pol. 2018, 65, 341-349. [CrossRef]

22. Renoux, F.; Stellato, M.; Haftmann, C.; Vogetseder, A.; Huang, R.; Subramaniam, A.; Becker, M.O.; Blyszczuk, P.; Becher, B.; Distler, J.H.; et al. The AP1 Transcription Factor Fosl2 Promotes Systemic Autoimmunity and Inflammation by Repressing Treg Development. Cell Rep. 2020, 31, 107826. [CrossRef]

23. Eferl, R.; Zenz, R.; Theussl, H.C.; Wagner, E.F. Simultaneous generation of fra-2 conditional and fra-2 knock-out mice. Genesis 2007, 45, 447-451. [CrossRef]

24. Venalis, P.; Kumánovics, G.; Schulze-Koops, H.; Distler, A.; Dees, C.; Zerr, P.; Palumbo-Zerr, K.; Czirják, L.; Mackevic, Z.; Lundberg, I.E.; et al. Cardiomyopathy in Murine Models of Systemic Sclerosis. Arthritis Rheumatol. 2014, 67, 508-516. [CrossRef] [PubMed]

25. Zhang, Y.; Shen, L.; Zhu, H.; Dreissigacker, K.; Distler, D.; Zhou, X.; Györfi, A.H.; Bergmann, C.; Meng, X.; Dees, C.; et al. PGC-1 $\alpha$ regulates autophagy to promote fibroblast activation and tissue fibrosis. Ann. Rheum. Dis. 2020, 79, 1227-1233. [CrossRef] [PubMed]

26. Patel, A.S.; Lin, L.; Geyer, A.; Haspel, J.A.; An, C.H.; Cao, J.; Rosas, I.O.; Morse, D. Autophagy in Idiopathic Pulmonary Fibrosis. PLoS ONE 2012, 7, e41394. [CrossRef] [PubMed]

27. Song, Y.; Zhao, Y.; Wang, F.; Tao, L.; Xiao, J.; Yang, C. Autophagy in Hepatic Fibrosis. BioMed Res. Int. 2014, 2014, 1-8. [CrossRef]

28. Ding, Y.; Choi, M.E. Regulation of autophagy by TGF-beta: Emerging role in kidney fibrosis. Semin. Nephrol. 2014, 34, 62-71. [CrossRef] [PubMed]

29. Cadwell, K.; Patel, K.K.; Maloney, N.S.; Liu, T.C.; Ng, A.C.; Storer, C.E.; Head, R.D.; Xavier, R.; Stappenbeck, T.S.; Virgin, H.W. Virus-plus-susceptibility gene interaction determines Crohn's disease gene Atg16L1 phenotypes in intestine. Cell 2010, 141, 1135-1145. [CrossRef] [PubMed]

30. Wang, Q.J.; Ding, Y.; Kohtz, D.S.; Mizushima, N.; Cristea, I.M.; Rout, M.P.; Chait, B.T.; Zhong, Y.; Heintz, N.; Yue, Z. Induction of autophagy in axonal dystrophy and degeneration. J. Neurosci. 2006, 26, 8057-8068. [CrossRef] [PubMed]

31. Dello Russo, C.; Lisi, L.; Feinstein, D.L.; Navarra, P. mTOR kinase, a key player in the regulation of glial functions: Relevance for the therapy of multiple sclerosis. Glia 2013, 61, 301-311. [CrossRef]

32. Lucin, K.M.; O’Brien, C.E.; Bieri, G.; Czirr, E.; Mosher, K.I.; Abbey, R.J.; Mastroeni, D.F.; Rogers, J.; Spencer, B.; Masliah, E.; et al. Microglial Beclin 1 Regulates Retromer Trafficking and Phagocytosis and Is Impaired in Alzheimer's Disease. Neuron 2013, 79, 873-886. [CrossRef]

33. Winslow, A.R.; Chen, C.-W.; Corrochano, S.; Acevedo-Arozena, A.; Gordon, D.E.; Peden, A.A.; Lichtenberg, M.; Menzies, F.M.; Ravikumar, B.; Imarisio, S.; et al. $\alpha$-Synuclein impairs macroautophagy: Implications for Parkinson's disease. J. Cell Biol. 2010, 190, 1023-1037. [CrossRef] [PubMed]

34. Voss, V.; Senft, C.; Lang, V.; Ronellenfitsch, M.W.; Steinbach, J.P.; Seifert, V.; Kögel, D. The Pan-Bcl-2 Inhibitor (-)-Gossypol Triggers Autophagic Cell Death in Malignant Glioma. Mol. Cancer Res. 2010, 8, 1002-1016. [CrossRef] [PubMed]

35. Mancias, J.D.; Kimmelman, A.C. Targeting Autophagy Addiction in Cancer. Oncotarget 2011, 2, 1302-1306. [CrossRef] [PubMed] 
36. Nakagawa, I.; Amano, A.; Mizushima, N.; Yamamoto, A.; Yamaguchi, H.; Kamimoto, T.; Nara, A.; Funao, J.; Nakata, M.; Tsuda, K.; et al. Autophagy Defends Cells Against Invading Group A Streptococcus. Science 2004, 306, 1037-1040. [CrossRef] [PubMed]

37. Schiattarella, G.G.; Hill, J.A. Therapeutic targeting of autophagy in cardiovascular disease. J. Mol. Cell. Cardiol. 2016, 95, 86-93. [CrossRef] [PubMed]

38. Oyabu, J.; Yamaguchi, O.; Hikoso, S.; Takeda, T.; Oka, T.; Murakawa, T.; Yasui, H.; Ueda, H.; Nakayama, H.; Taneike, M.; et al. Autophagy-mediated degradation is necessary for regression of cardiac hypertrophy during ven-tricular unloading. Biochem. Biophys. Res. Commun. 2013, 441, 787-792. [CrossRef]

39. Sotthibundhu, A.; Promjuntuek, W.; Liu, M.; Shen, S.; Noisa, P. Roles of autophagy in controlling stem cell identity: A perspective of self-renewal and differentiation. Cell Tissue Res. 2018, 374, 205-216. [CrossRef]

40. Del Principe, D.; Lista, P.; Malorni, W.; Giammarioli, A.M. Fibroblast autophagy in fibrotic disorders. J. Pathol. 2013, 229, 208-220. [CrossRef]

41. Kawano, S.; Torisu, T.; Esaki, M.; Torisu, K.; Matsuno, Y.; Kitazono, T. Autophagy promotes degradation of internalized collagen and regulates distribution of focal adhesions to suppress cell adhesion. Biol. Open 2017, 6, 1644-1653. [CrossRef] [PubMed]

42. Füllgrabe, J.; Ghislat, G.; Cho, D.-H.; Rubinsztein, D.C. Transcriptional regulation of mammalian autophagy at a glance. J. Cell Sci. 2016, 129, 3059-3066. [CrossRef]

43. Reich, N.; Maurer, B.; Akhmetshina, A.; Venalis, P.; Dees, C.; Zerr, P.; Palumbo, K.; Zwerina, J.; Nevskaya, T.; Gay, S.; et al. The transcription factor Fra-2 regulates the production of extracellular matrix in systemic sclerosis. Arthritis Rheum. 2009, 62, 280-290. [CrossRef] [PubMed]

44. Sun, T.; LiangPing, X.; Wang, L.; Xia, L.; Ma, J.; Guan, Z.; Feng, G.; Zhu, X. c-Jun NH2-terminal kinase activation is essential for up-regulation of LC3 during ceramide-induced autophagy in human nasopharyngeal carcinoma cells. J. Transl. Med. 2011, 9, 161. [CrossRef]

45. Yogev, O.; Goldberg, R.; Anzi, S.; Yogev, O.; Shaulian, E. Jun proteins are starvation-regulated inhibitors of autophagy. Cancer Res. 2010, 70, 2318-2327. [CrossRef] [PubMed]

46. Chatre, C.; Roubille, F.; Vernhet, H.; Jorgensen, C.; Pers, Y.M. Cardiac Complications Attributed to Chloroquine and Hydroxychloroquine: A Systematic Review of the Literature. Drug Saf. 2018, 41, 919-931. [CrossRef]

47. Schrezenmeier, E.; Dörner, T. Mechanisms of action of hydroxychloroquine and chloroquine: Implications for rheumatology. Nat. Rev. Rheumatol. 2020, 16, 155-166. [CrossRef] [PubMed]

48. Ucero, A.C.; Bakiri, L.; Roediger, B.; Suzuki, M.; Jimenez, M.; Mandal, P.; Braghetta, P.; Bonaldo, P.; Paz-Ares, L.; Fustero-Torre, C.; et al. Fra-2-expressing macrophages promote lung fibrosis in mice. J. Clin. Invest. 2019, 129, 3293-3309. [CrossRef] [PubMed]

49. Chai, Q.; Onder, L.; Scandella, E.; Gil-Cruz, C.; Perez-Shibayama, C.; Cupovic, J.; Danuser, R.; Sparwasser, T.; Luther, S.A.; Thiel, V.; et al. Maturation of lymph node fibroblastic reticular cells from myofibroblastic pre-cursors is critical for antiviral immunity. Immunity 2013, 38, 1013-1024. [CrossRef] [PubMed]

50. Hara, T.; Nakamura, K.; Matsui, M.; Yamamoto, A.; Nakahara, Y.; Suzuki-Migishima, R.; Yokoyama, M.; Mishima, K.; Saito, I.; Okano, H.; et al. Suppression of basal autophagy in neural cells causes neurodegenerative disease in mice. Nature 2006, 441, 885-889. [CrossRef] 